\title{
Assessing the Impact of Exchange Rate Volatility on the Competitiveness of South Africa's Agricultural Exports
}

\author{
Ajuruchukwu Obi ${ }^{1}$, Portia Ndou ${ }^{1}, \&$ Bathathu Peter ${ }^{1}$ \\ ${ }^{1}$ Department of Agricultural Economics \& Extension, University of Fort Hare, Alice Private Bag X1314, Alice, \\ South Africa \\ Correspondence: Ajuruchukwu Obi, Department of Agricultural Economics \& Extension, University of Fort Hare, \\ Alice Private Bag X1314, Alice, South Africa. Tel: 270-73-313-1865. E-mail: aobi@ufh.ac.za
}

$\begin{array}{lc}\text { Received: March 18, } 2012 & \text { Accepted: May 31, } 2013 \quad \text { Online Published: September 15, } 2013 \\ \text { doi:10.5539/jas.v5n10p227 } & \text { URL: http://dx.doi.org/10.5539/jas.v5n10p227 }\end{array}$

\begin{abstract}
The fluctuations of the exchange rate of the domestic currency have been a major concern. Since the 1970's there has been a debate on the relationship between exchange rate volatility and export flows. In the wake of the recent global financial crisis and rising food prices, this debate has become even more strident and the concerns even more palpable. South Africa has not escaped the debate. The exchange rate of the South African Rand has been undergoing a series of devaluations for several decades. In such a situation, exporters must contend with some exchange rate volatility which might have implications for export flows. However, in the absence of systematic study, neither the magnitude of the fluctuations nor their impacts is known with certainty and this presents immense policy difficulties. This paper seeks to provide answers to the most commonly asked question as to the magnitude and extent of such fluctuations and their precise impacts on export levels and the market shares of South African citrus exports in the destination markets around the world. The principal objective it to estimate the impact of exchange rate volatility on the competitiveness of South Africa's agricultural exports. The paper reviews the theoretical literature in respect to foreign exchange market, Balance of Payments, exchange rate models and the evidence from monetarists and the Purchasing Power Parity. Laspeyres-indexed export prices, exchange rates and export volumes for maize, oranges, sugar, apples, grapes, pears, avocados, pineapples, apricots and peaches for the period 1980-2008 and exports to the European Union are modeled by means of ARIMA (AR) and Autoregressive Conditional Heteroscedasticity (ARCH) and export demand equation estimated. The Constant Market Share (CMS) model was applied to assess the extent to which the SA citrus industry has maintained its competitive advantage in several markets. The overall results obtained strongly confirm that exchange rate volatility have a positive impact on the competitiveness of South Africa's agricultural exports and that, despite the on-going financial crisis that has engulfed the world, South Africa's citrus exports have maintained a healthy market share. This result is surprising but understandable in the light of the special arrangements put in place by South Africa's monetary authorities to protect the Rand from over-exposure to global financial developments over the period under review. The important practical implications of these findings for the success of the agricultural restructuring programmes going on in South Africa are evaluated and discussed against the backdrop of the fresh debates on national economic policy management in the wake of financial meltdown that has once again threatened the financial stability of virtually every region in the world in recent years.
\end{abstract}

Keywords: exchange rates, volatility, agricultural exports, citrus industry, time series analysis, European Union, $\mathrm{ARCH} / \mathrm{GARCH}$, constant market share, competitiveness

\section{Introduction and Problem Context}

Exchange rates have fluctuated widely since the 1970's especially after the collapse of the Bretton Woods system of fixed exchange rates in 1973 (Van der Merwe, 1997 as well as Todani \& Munyama, 2005). Since then, there has been a proliferation of documentation, arguments and debates on the relationship between the exchange rate and exports flows. In international trade theory, the most commonly held belief is that exchange rate volatility depresses trade thereby increasing the riskiness of international trading activity.

South Africa has not escaped the debate and the associated riskiness in both the agricultural and industrial sectors of the economy. Since 1973, the high degree of exchange rate volatility has posed a serious challenge to policy makers, not least because the magnitude of its impacts on trade flows is unknown. There is clear and widespread 
recognition that an investigation into the nature and extent of exchange rate impact on trade volumes will be helpful from the point of view of efforts to enhance the internationalization of agri-food chains. As is well-known, the democratic leadership in South Africa has been pursuing a policy of black economic empowerment in agriculture in the post-Apartheid era and enhancing markets access both domestically and internationally is an important element of the schemes. The absence of the needed insights into the extent of the exchange rate volatility and its impacts currently poses serious problems for policy making with important practical implications for the success of the on-going programmes and ultimately the health of the entire economy.

In a highly volatile environment, export producers and the profit maximizing firms are unable to anticipate trade and income earnings due to the increased risks associated with exchange rate movements. The volatile exchange rate risk becomes a problem to the export-led economies because it affects the export price which tends to increase the risk and uncertainty of international transactions. Research is essential to gain sufficient insight to contribute to the debates as well as economic policy making on the subject matter.

In the first instance, the possible effects of the exchange rate volatility on the competitiveness of South Africa's agricultural exports need to be understood. Van der Merwe (2007) argues that the extent of the South African exchange rate volatility is probably related to the uncompetitive production and export structure of the country. Exporting agricultural products might be a challenge for South Africa because of the risks associated with exchange rate volatility. Exporting countries are faced with the risk of not making profits or outright loss because of exchange rate volatility as well as uncompetitive production. In this situation, risk averse exporters might not be willing to participate in trade because of high risks associated, with adverse consequences for export revenues, the overall health of the economy and efforts to achieve poverty reduction and economic empowerment of the farming households. For a country like South Africa where unemployment rates are high and rising and poverty reduction is a central public policy goal, such a prospect is disquieting.

The rest of this paper is structured as follows: section 2 presents the research objectives and hypotheses, while section 3 presents the literature review on the effects of exchange rate volatility on exports while section 4 presents the model and methodology. The empirical results are presented in section 5 separately for the key components of the paper, viz, stationarity tests and long-term relationships, vector error correction and short-run relationships, extent of volatility, primary agricultural exports, and constant market shares. Section 6 concludes the paper.

\section{Research Objectives and Hypothesis}

Fundamentally, the objective of the paper is to examine the impact of exchange rate volatility on the competitiveness of South Africa's agricultural exports. Specifically, the paper will:

- determine the direct effect of exchange rate on South African exports

- assess the effect of foreign income on exports and

- investigate the effect of export price on exports

- determine possible changes in market share of South African citrus

- make recommendations for policy and research

In line with the foregoing, the working hypothesis of this paper is that exchange rate of the South African Rand is negatively related to South Africa's agricultural exports and the international competitiveness of the agricultural sector. Therefore, the following hypotheses are tested:

$\mathrm{H}_{\mathrm{O}}$ : Exchange rate volatility depresses South Africa's agricultural export competitiveness;

$\mathrm{H}_{\mathrm{A}}$ : Exchange rate volatility does not depress South Africa's agricultural export competitiveness.

\section{Literature Review}

Many studies have been carried out to show how exchange rate volatility affects the pattern and level of trade between nations. Much work has been devoted into clarifying the concept of exchange rate volatility as well as the different ways in which it can be measured and its wider impact assessed. According to Sun et al. (2002), it is the uncertainties about exchange rates that drive international trade whereas the specific effects of exchange rate volatility on exports remain indeterminate and controversial. In a study that examined this problem for the United States and the OECD Countries, Kafle and Kennedy (2012) found that exchange rate volatility has a greater impact on the agricultural sector, while the real exchange rate has a greater impact on the non-agricultural sector.

Fabiosa (2002), in his working paper, examined the impacts of the exchange rate and its volatility on pork and live swine exports and a model of a representative Canadian pork exporter was developed. The pork export supply equation was expressed as a function of the expected level of real exchange rate and a time-varying variance of real 
exchange rate. The same model was used to examine the sensitivity of pork exports to Japan from Canada, the United States and Denmark. The parameters of all pork and live swine in export equations were theoretically consistent and many were significant. The results show that, the domestic price in the exporting country has a negative effect on exports because it is a major input price in the exporter's cost function while the price in the market of destination has a positive effect. The level of the exchange rate was found to have a positive impact on pork exports while the volatility of the exchange rate has a negative impact. Most of the volatility parameters were not significant. In Ghana, Bhattarai and Armah (2005) confirm a stable long-run relationship between both exports and imports and the real exchange rate. They also found that when the domestic currency weakens, that is devaluation; the effect on both imports and exports is contractionary. Examining the impact of exchange rate volatility on South African export flows, Todan and Munyama (2005) and Takaendesa, Tsheole and Aziakpono (2005), came to more or less same conclusion in respect to the differential impacts on agricultural and non-agricultural exports.

In terms of the estimation techniques employed to assess the impact of exchange rate volatility on exports, diverse approaches are evident. The most significant steps have generally been seen as those made by Box and Jenkins (1970) whose formalized the ARIMA (Auto-Regressive Integrated Moving Averages) methodology. Their work was followed by the landmark contributions of Engle (1982) in the form of ARCH (Auto-Regressive Conditional Heteroskedasticity) - type modeling. The ARCH model in which the unconditional variance is constant was the basis for the work of Akgul and Sayyan (2008). By this approach, Engle (1982) introduced the notion of modeling in which lagged disturbances are an important component. Without a doubt, the introduction of the AutoRegressive Conditional Heteroscedasticity model (ARCH) in Engle (1982) is easily epoch-making and afforded researchers and practitioners the flexibility for modeling volatility (Evans \& MacMillan 2007). Essentially, the ARCH methodology allows for the modeling of exchange rate trends over time, with its other variations being GARCH (Bollerslev, 1986) which is one way that joint estimation of the conditional mean model and the variance can be achieved.

To estimate the impact of exchange rate volatility on UK exports to the European Union (EU), De Vita and Addot (2004) employed the Auto-Regressive Distributed Lag (ARDL) econometric techniques which Todan and Munyama (2005) and Takaendesa et al. (2005) applied to their South African studies. In those procedures, export demand equation was estimated using disaggregated monthly data for the period 1993 to 2001 and the conclusion drawn was that the UK exports to the EU are largely unaffected by exchange rate volatility. For the Ghanaian study (Bhattarai \& Armah, 2005), annual time series data from 1970-2000 were employed to estimate trade balance as a function of the real exchange rate, domestic and foreign incomes by means of cointegration analysis.

Salvatore (2007) suggests that elasticity approach is one of the most commonly used approaches to assess the exchange rate impacts on the balance of payments equilibrium. This approach assesses the impact of exchange rate movements on trade balance by determining the response of exports and import with respect to changes in prices arising from changes in exchange rate volatility. The reaction in these markets is simply a functioning of supply and demand elasticities. In this respect, McAfee (2006) defines elasticity as "the ratio of percentage change in quantity demanded to a change in price".

The other approach that has been regularly used by researchers is the gravity equation model. In the way it was used by Cameron, Kihangire and Potts (2001), the model estimated the bilateral trade flows between countries as depending positively on the product of their GDP's and negatively related to their geographical distance from each other.

The Constant Market Share (CMS) analysis involves decomposition of an identity (Ahmadi-Esfahani, 2006). The Constant Market Share (CMS) model was developed by Tyszynski (1951) and later refined by Milana (1988). The model measures a country's share of world exports in a particular commodity or other export items. It is based on the assumption that an industry should maintain its export share in a given market (i.e. remain unchanged over time). If a country's share of total products exports is growing in relation to competitors, for example, this may reflect increasing competitiveness of that country's product sector (Siggel, 2006).

\section{The Model and Methodology}

The questions posed are conventionally handled by two parallel approaches, namely the application of the co-integration analysis methodology of econometrics, and the application of the constant market share model. These approaches are briefly described in the next few sections below. 


\subsection{The Co-Integration Model}

The first approach deals with the estimation of an export demand equation whereby real exports is the function of income from South Africa's trading partner (Europe), relative prices and exchange rate volatility. Cameron, Kihangire \& Potts (2001) and others used both export supply and demand equations, while others have used the gravity model to estimate the impacts of exchange rate volatility on export flows. Therefore, the model to be estimated is in the following form:

$$
\mathrm{X}=\beta_{0}+\beta_{1} \text { Inc }+\beta_{2} \mathrm{Px}+\beta_{3} \mathrm{~V}+\xi
$$

Where: $\mathrm{X}=$ real agricultural exports,

Inc $=$ foreign income,

$\mathrm{Px}=$ the price of exports which will serve as an indicator of international competitiveness

$\mathrm{V}=$ the exchange rate volatility,

$\beta=$ the constant and

$\xi=$ normally distributed error term.

Equation (1) indicates that real exports depend on income of our trading partners (i.e foreign income), among other variables, as well as the risk associated with exchange rate volatility. In order to boost the strength of the model and avoid spurious regression it is very important to carry out log transformation of the variables (Brooks, 2006).

$$
\ln \mathrm{X}=\beta_{0}+\beta_{1} \ln \text { Inc }+\beta_{2} \ln \mathrm{Px}+\beta_{3} \ln \mathrm{V}+\xi
$$

where: $\ln$ denotes the log values of each variable defined in Equation (1).

The variables that are included in the model presented in Equations (1) and (2) are discussed in details.

\section{(a) Exports $(\ln \mathrm{X})$}

The composite index of agricultural exports is defined as the dependent variable. Time series data for the period starting from 1980/81 to 2005/06 production year is selected for the variable. The Laspeyres indexation of the top ten South Africa's agricultural export namely; maize, oranges, sugar, apples, grapes, pears, avocados, pineapples, apricots and peaches was computed to represent the composite index for exports. Figure 1 below, shows the trends of South Africa's agricultural exports for the selected sample period.

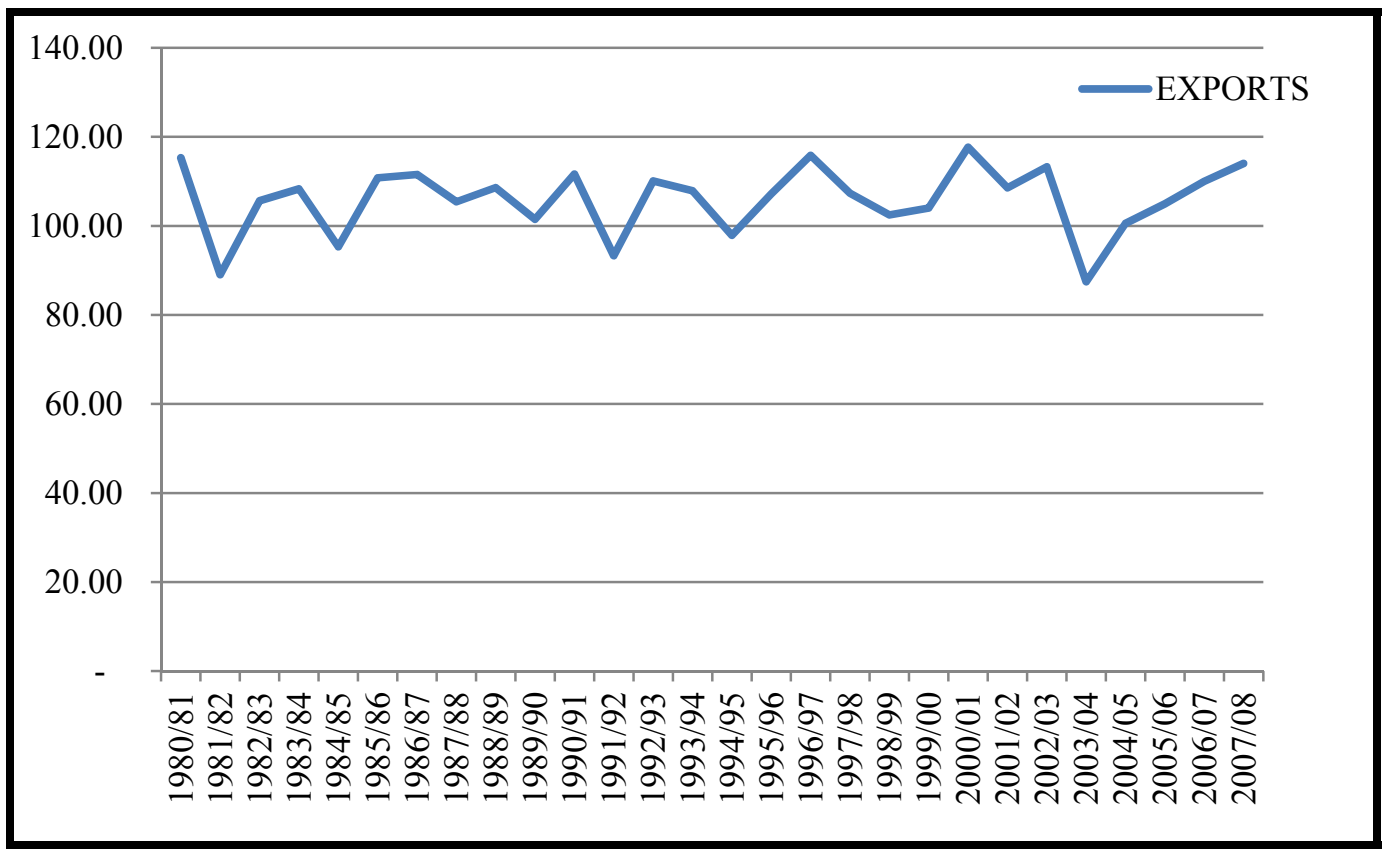

Figure 1. Showing agricultural exports from 1980/81 to 2005/06 
In 1980/81, 1996/79 and 2000/01 as well as 2002/03 production year, exports were high at an index of almost 118 per year. The reason for this might be an increased production due to the favourable growing conditions. In 1981/82 and 2003/04 production year, exports depreciated slightly to an average index of about 83 for the year. Overall, the exports ranged between index of 80 and 120 per year. This shows that the variations have been managed well by the trade policies in place.

(b) Foreign income ( $\ln$ Inc)

The demand for any consumer is hardly affected by the changes in income. Foreign income is selected as one of the explanatory variables that will be able to determine the external demand for South Africa's agricultural exports. Foreign income for Europe is selected since it is the South Africa's main trading partner for agricultural exports.

The sample period for this variable starts from 1980/81 to 2007/08. Figure 2 below presents the trends shown by the foreign income in Euros for the selected sample period.

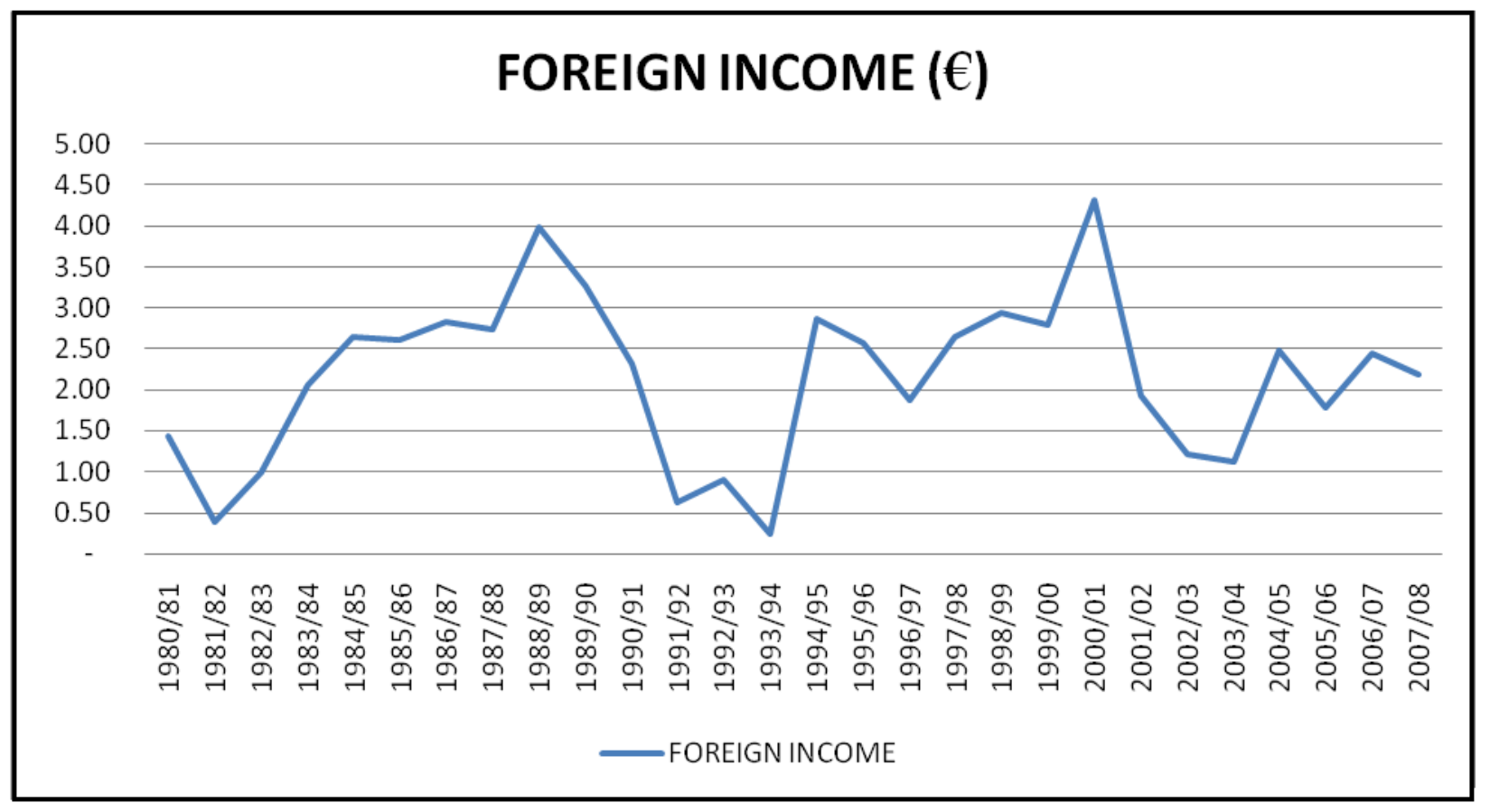

Figure 2. Showing foreign income from 1980/81 to 2007/08

The variable is more volatile though out the period. This is because it is strongly affected by the changes of the trade between countries. In early 1980s and 1990s, income for European countries has dropped drastically. This might be related to the changes in the value of their currency and economics activity in those periods. In early 1980s and early 2000s, foreign income has increased.

(c) Price of exports $(\ln \mathrm{Px})$

Agricultural export prices are included in the model and defined as the explanatory variable. The inclusion of the variable intends to capture the export competitiveness of agricultural export competitiveness to the rest of the world. Price of exports has been used widely by researchers like Fountas \& Aristotelous (1999) as the indicator of export competitiveness. Consumers always consider the lowest possible price. In order to earn highest market share to the EU market South Africa must offer highly competitive prices than to the rest of the world. This variable is highly affected by the changes of domestic currency of the country.

Figure 3 below presents the trends of the export prices for South Africa's agricultural export for the selected sample period. 


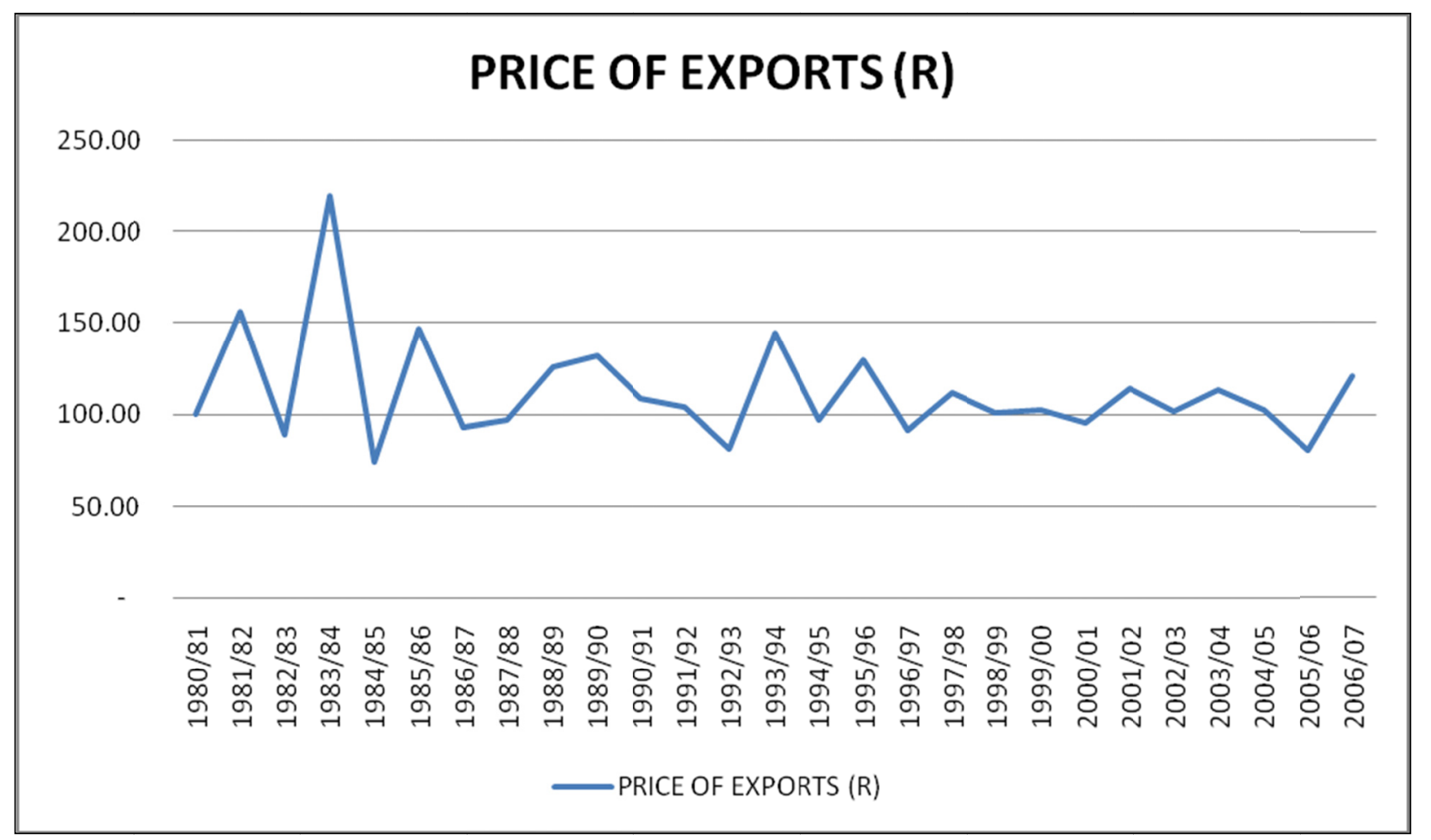

Figure 3. Showing price of South Africa's agricultural export from 1980/81 to 2006/07

By mid 1980s there have been wide swings in the price of exports. The variations might have been as the result of the collapse of the Bretton Woods system of fixing the exchange rate as discussed earlier. From the late 1980s, price has been almost stabilized throughout the period.

(d) Exchange rate volatility $(\ln \mathrm{V})$

The major interest is the relationship between the exchange rate of the Rrand and export flows. The value of the South African Rand to the Euro is considered for this variable. Figure 4 below presents the trends of exchange rate volatility for South African Rand against Euro for the selected period. 


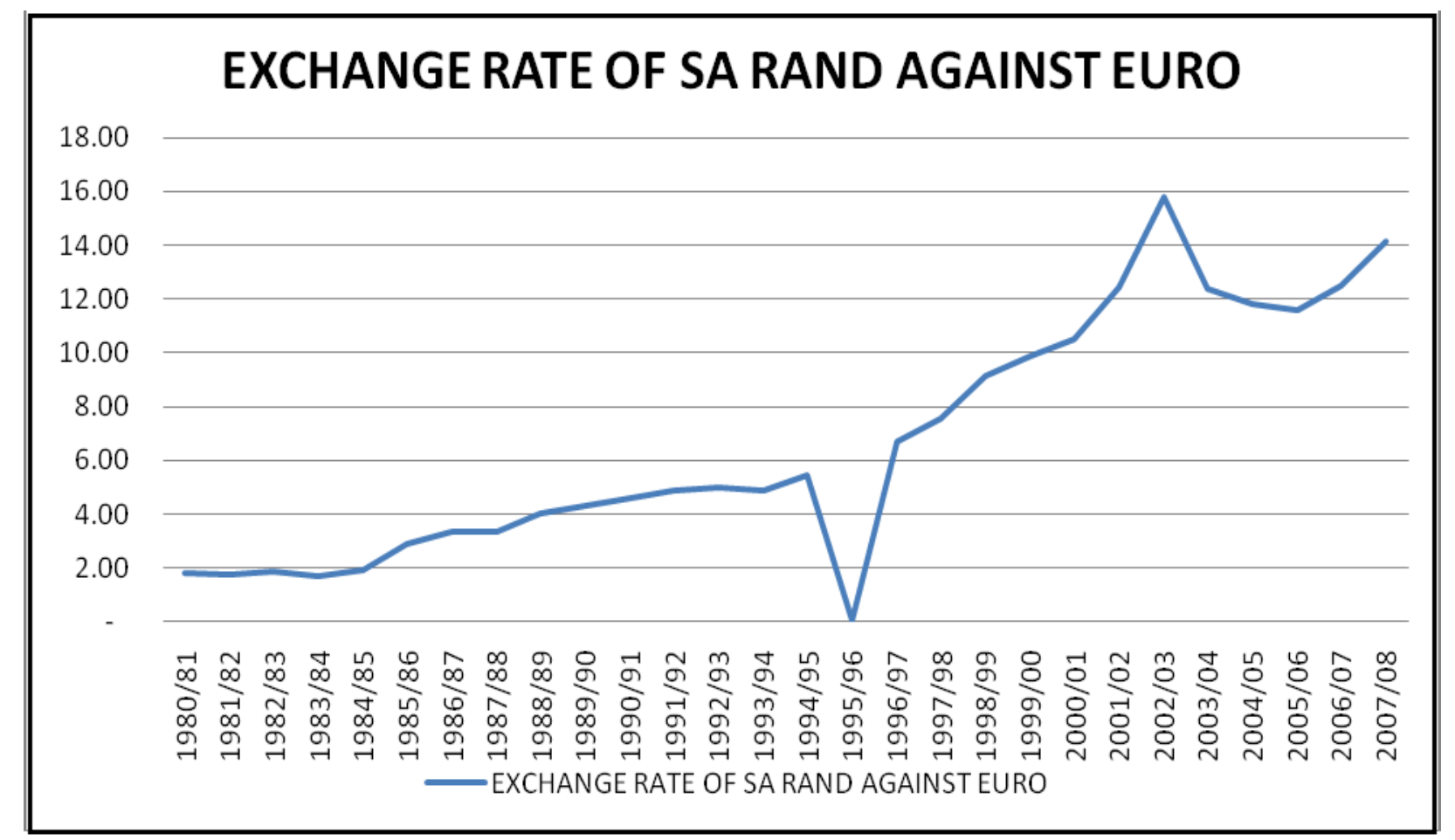

Figure 4. Showing exchange rate volatility from $1980 / 81$ to $2007 / 08$

In early 1980s, South African rand was stronger against the Euro. South African currency lost its value drastically after mid 1980s and hit the highest record of R16 per Euro in early 2000s. Because South Africa is a small country, the value South African rand is affected by the events that happen to the rest of the world. The highest record in early 2000s might be the cause the September 11 attacks that happened in the United States.

Unit root tests were conducted in line with the following expressions:

$$
Y_{t}=p_{a} y_{t-1}+\mu_{t}
$$

Or

$$
(1-L) y_{t}=\Delta y_{t}=\left(p_{a}-1\right) y_{t-1}+\mu_{t} \quad \quad \mu_{t} \sim \operatorname{IID}\left(0, \sigma^{2}\right)
$$

The following is the hypothesis to be tested when testing the unit root:

$$
\begin{aligned}
& H_{0}: p_{a}=1 \\
& H_{1}: p_{a}<1
\end{aligned}
$$

Equation 4 is the most advantageous and simple procedure to follow when testing $\left(p_{a}-1\right)=p_{a}^{*}=0$; especially when a more complicated $\operatorname{AR}(p)$ processes is considered in the second form of the test. To test the hypothesis, a standard $\mathrm{t}$ - test approach is used. Under the non-stationarity, the statistic computed does not follow a standard t-distribution but the Dickey-Fuller distribution. Brooks (2006) elaborated that, there are models under the null hypothesis and the alternative hypothesis can be based on, the following are the three cases namely:

$$
\text { (i) } \begin{aligned}
\mathrm{H}_{0} & : y_{t}=y_{t-1}+\mu_{t} \\
\mathrm{H}_{1} & : y_{t}=p y_{t-1}+\mu_{t}, p<1 \\
\mathrm{H}_{0} & : y_{t}=y_{t-1}+\mu_{t} \\
\mathrm{H}_{1} & : y_{t}=p y_{t-1}+\mu+\mu_{t}, p<1 \\
\mathrm{H}_{0} & : y_{t}=y_{t-1}+\mu_{t} \\
\text { (iii) } \quad \mathrm{H}_{1}: y_{t} & =p y_{t-1}+\mu+\lambda_{t}+\mu_{t}, p<1
\end{aligned}
$$

Where hypotheses in (i) being the test for a random walk against a stationary autoregressive process of order one $\mathrm{AR}(1)$; (ii) a tests for a random walk against a stationary AR(1) with drift and (iii) a test for a random walk against 
a stationary $\operatorname{AR}(1)$ with drift and a deterministic time trend. The null hypotheses for all the three tests can also be written as $\Delta y_{t}=\mu_{t}$.

Assuming that $y_{t}$ follows the $p$ th order autoregressive process, the following equation was estimated:

$$
y_{t}=\psi_{1} y_{t-1}+\psi_{2} y_{t-2}+\ldots \Psi_{p} y_{t-p}+\mu_{\mathrm{t}}
$$

When the lagged values of the dependent variable $\Delta y_{t}$. are added to augment the foregoing models, the following $\mathrm{ADF}$ test equation is estimated:

$$
\Delta y_{t-1}=\psi^{*} y_{t-1}+\sum_{\psi * y t-1}^{p-1}+\mu+y t+\mu_{t} \quad \mu_{t} \sim \operatorname{IID}\left(0, \sigma^{2}\right)
$$

In Equation (14) above, $\mu_{t}$ is a white noise error term and $\psi^{*}=\left(\psi_{1}+\psi_{2} \ldots+\psi_{p}\right)-1$. If $\psi^{*}=0, y_{t}$ contains the unit root. The model can be extended to allow for moving-average (MA) parts in the $\mu_{t}$. The MA is said to be present in the error term in various time series after first differencing.

The following is the model $z_{t}$ as an unrestricted vector auto regression (VAR) with up to k-lags of $z_{t}$ :

$$
\mathrm{z}_{\mathrm{t}}=\mathrm{A}_{1} \mathrm{z}_{\mathrm{t}-1}+\ldots+\mathrm{A}_{\mathrm{k}} \mathrm{z}_{\mathrm{t}-\mathrm{k}}+\mathrm{u}_{\mathrm{t}} \quad \mathrm{u}_{\mathrm{t}} \sim \operatorname{IN}(0, \Sigma)
$$

In Equation (15) above, $z_{t}$ is ( $\left.n \times 1\right)$ and each of $A_{i}$ is an ( $\left.\mathrm{n} \times n\right)$ matrix parameter.

When the long-run cointegration relationships are obtained using the Johansen approach, at this particular point in time we can reformulate our model and estimate the Vector Error Correction Model (VECM) with the inclusion of the error correction term as follows:

$$
\Delta \mathrm{z}_{\mathrm{t}}=\Gamma_{1} \Delta \mathrm{z}_{\mathrm{t}-1}+\Gamma_{2} \Delta \mathrm{z}_{\mathrm{t}-2}+\Gamma_{3} \Delta \mathrm{z}_{\mathrm{t}-3}+\alpha\left(\beta_{1}^{\prime} \mathrm{z}_{\mathrm{t}-1}+\beta_{2}^{\prime} \mathrm{z}_{\mathrm{t}-1}\right)+\psi \mathrm{D}_{\mathrm{t}}+\mathrm{u}_{\mathrm{t}}
$$

In Equation 16 above, $z_{t}$ may enter the error correction term with a lag of $t-1$ or $t-k$ since they can be shown to be equal. The OLS is an efficient way to estimate equation 16 if a common set of regressors exists. Since all variables in the model are now $I(0)$, the statistical inference using the standard t-test and F-test is suitable.

$Z$ defines the long-term relationship between variables $\mathrm{Z}$ and $\mathrm{D}$ and the short-run relationship is described by $\Gamma_{1}, \Gamma_{2}$ and $\Gamma_{3}$ between changes in $Z$ and $D$. The $\alpha$ is the strict definition that measures the proportion of the last period equilibrium error and it describes the speed of adjustment back to equilibrium.

$$
\begin{aligned}
& Y_{1 t}=\beta_{10}+\beta_{11} \mathrm{y}_{1 \mathrm{t}-1}+\alpha_{11} y_{2 t-1}+u_{1 t} \\
& Y_{2 t}=\beta_{20}+\beta_{21} \mathrm{y}_{2 \mathrm{t}-1}+\alpha_{21} y_{1 t-1}+u_{2 t}
\end{aligned}
$$

\subsection{The Constant Market Share Model}

For purposes of determining the competitiveness of the citrus exports, the Constant Market Share (CMS) model was used. The CMS measures the competitiveness of the industry of interest in the export market. It is based on the disintegration of variations occurring either in their exports or in their market shares.

This study measured the competitiveness of the South African citrus against its major rivals: Spain, USA, Turkey, China and Morocco. Secondary data were basically composed of trade figures and destinations to which the fruit and other citrus products were marketed internationally. Survey data were obtained on the basis of semi-structured questionnaires. The variables modeled were the SA's country's citrus exports, the market share of the exporting country in the export market, and the total imports of the markets. In general, the purpose was to examine the impact of the determinants of competitiveness. Based on Barbaros, Akgungor, Aydogus (2007), the CMS model is specified as follows:

$$
\Delta q=\sum_{i j} \sum_{i j}^{o} \Delta q_{i j}+\sum_{i} \sum_{j} Q_{j}^{o} \Delta S_{i j}+\sum_{i j} \sum_{j} \Delta S_{i j} \Delta Q_{i j}
$$

$$
[1] \quad[3]
$$

Where,

$\mathrm{q}=$ target country's citrus exports (value)

$\mathrm{S}_{i j}=$ An exporter country's export market share of product $i$ (where there are more than one selected products) in country $j$ (more than one selected countries)

$\mathrm{Q}_{i j}=$ Total imports of market $j$

$\Delta=$ annual change 
$0=$ base year

The model above has three components on the right hand side which constitute the main elements of constant market share, namely (1) the structural or market effect, (2) the competitive effect and (3) the second-order effect (Chen \& Duan, 2001).

The CMS has as its basis, the assumption that an industry should maintain its export share in a given market (i.e. remain unchanged over time). The impact of these forces on similar industries may result in different but independent reactions and volumes exported to the same market outlet. In addition, there are differences in home base environmental factors affecting the imports coming from varying countries into a single market.

Table 1. Data analysis and proposed measurement criterion

\begin{tabular}{|c|c|c|}
\hline Variable & Description & Measurement criterion or indicator \\
\hline Export competitiveness & $\begin{array}{l}\text { A microeconomics concept since it focuses on a } \\
\text { single industry } \\
\text { Static concept } \\
\text { Deterministic (measures costs, prices, market } \\
\text { shares etc, which are observed and reflect actual } \\
\text { performance) }\end{array}$ & Market Share Analysis \\
\hline $\begin{array}{l}\text { Major environmental } \\
\text { challenges }\end{array}$ & $\begin{array}{l}\text { Dynamic concept of competitiveness which is } \\
\text { based on the identification of the determinants of } \\
\text { trade } \\
\text { Ex post nature of concept }\end{array}$ & $\begin{array}{l}\text { Diamond model (Porter, 1990, } \\
\text { 1998) } \\
10 \text { point Likert scale }\end{array}$ \\
\hline $\begin{array}{l}\text { Opportunities } \\
\text { sustained } \\
\text { competitiveness }\end{array}$ & $\begin{array}{l}\text { Stochastic (a number of other variables, which } \\
\text { are deemed to determine the competitiveness } \\
\text { according to models of a stochastic nature) } \\
\text { Ex ante nature of concept }\end{array}$ & $\begin{array}{l}\text { These variables were used as data } \\
\text { in statistical analysis of the } \\
\text { unobservable indicators }\end{array}$ \\
\hline Cost of compliance & Ex post nature of analysis & 3-Point Likert scale rating \\
\hline Non-price benefits & Ex post nature of analysis & 4-Point Likert scale rating \\
\hline $\begin{array}{l}\text { Institutional } \\
\text { arrangements } \\
\text { strategies }\end{array}$ & Ex ante nature of analysis & $\begin{array}{l}\text { Proposed based on the result } \\
\text { findings of the competitiveness of } \\
\text { the citrus industry. }\end{array}$ \\
\hline
\end{tabular}

The interpretation of the CMS model is based on the presumption that changes in market share reflect purely competitive conditions. Interpretation is thus a description of past trading pattern. Inevitably, inferences regarding the forces underlying the country's export performance may be the end result, thereby, resulting in an interpretation that is diagnostic. The CMS model does not describe the causes for any gains or losses of market shares. This aspect was however complemented through the use of Porter's diamond model.

Discrepancies in quantity and quality attributes demanded, as well as prices offered for each citrus cultivar led to the separation of the different types of citrus fruits in the analysis of the competitiveness of the South African citrus industry. Each type was considered separately. The CMS analysis adopted the following categories; oranges, grapefruit, lemons and limes as well as soft citrus. Various cultivars within each category were ignored. Also the citrus fruit juices were not considered for the analysis of the competitiveness of the industry.

Porter's diamond model (Porter, 1990 and 1998) was used for the identification of the major environmental factors influencing competitiveness and the extent to which they impact upon the performance of the industry. The advantage of the diamond model is that it evaluates all participants in the supply chain (Porter, 1990 and 1998). While the approach points out the weaknesses and strengths of a sector, it also identifies critical success factors in the supply chain to which special attention can be paid with the objective of developing and sustaining competitiveness as successfully as possible in years to come. It was thus imperative to identify key players (suppliers and other value chain members) in the citrus industry and apply this model in order to determine individual player and chain differentiations. A 10 point likert scale was used to indicate the degree to which each of these factors affected competitiveness or performance of the industry. Scores ranging between 0 and 10 against 
each determinant factor were assigned with a higher score indicating a more enhancing factor while a lower score denotes a more constraining factor. Most of the market side factors were categorised as demand factors within the diamond model e.g. SPS standards and import licensing. The important factors within each category are listed in detail in Table 2 below.

Table 2. The factors considered under each classification of the diamond model

\begin{tabular}{ll}
\hline Factor & Cost of production, Labour (labour relations, productivity, worker skills levels, staff training, \\
endowments & worker literacy, aptitude, worker attitude, availability of skilled employees, quality of labour), \\
& natural factors(climatic conditions, abundance, quality accessibility and cost of water), \\
& infrastructure (type, location, user cost e.g. transportation, communication systems, \\
& payments or fund transfer) Capital (cost, availability), Knowledge (cost, quality, availability \\
& of scientific, technical and market knowledge), Technology (cost, quality, availability, \\
& technical information flow, availability of scientific research
\end{tabular}

Demand Market size, market information, quality of products, market growth, size and growth in the Conditions local market, international market large enough to obtain economies of scale, economic stability, political stability, price stability, crime, SPS regulations, trade specifications, the challenges of management in an international environment, Non-tariff barriers

-quality and packaging requirements

-import licensing

-quotas

-Sanitary and Phytosanitary regulations

- Global Partnership for Good Agricultural Practice (GLOBALGAP)

- Hazard Analysis and Critical Control Points (HACCP)

- Codex Alimentarius Commission (Codex)

-import duties

Foreign market support regimes for fruits

-The reference price or minimum import price system

-The reference price system for citrus fruits in the EEC

-subsidies and price supports (by Canada, USA, Japan and the EC)

Related and Financial institutions, research institutions, transport companies, suppliers of packaging supporting materials, agricultural input suppliers, Electricity, related industries \& organisations industries (nurseries, CGA, Exporting companies e.g. CapeSpan, CRI, PPECB, FPEF)

Firm strategy, Adaptability, Culture, Structure, flexibility, pricing strategy, managerial capabilities, market structure and power of buyers, market power of suppliers, threat of substitutes, threat of new entrants, rivalry

Government

Indirect support, Trade Policy, Land reform policy, Labour policy, Fiscal policy (general economic policy), Education policy, Agricultural policy, Environment policy, Financial and taxation policy, Property rights issue, SA's BEE and transformation policies, impact of the tax system on investments and risk taking

Chance Crime

\section{HIV/AIDS}

The US plant quarantine Act

Oil and fuel prices, Fluctuations in the exchange rates, Inflation, Cultivar mix

Global Economic recession

A World Cup hosting by SA 


\section{Results of the Empirical Analysis}

The results of the empirical analysis are presented in this section, separately for the co-integration analysis and the constant market share analysis before being jointly interpreted to draw conclusions in respect to the effects of exchange rate volatility on competitiveness and market shares of South African exports.

\subsection{Stationarity Tests and Long-Term Relationships}

Figures 5 and 6 present the results of the plots of the raw data and the logarithms of all the variables included in the model. The exchange rate and price of exports exhibit considerable trends in the raw data and in the logarithmic form. This gives some insight on the relationship that should be expected between the two variables. Exports were relatively stable in both figures except after 2002 when there seemed to have been a drastic fall following the weakened Rand exchange rate and export price during that period.

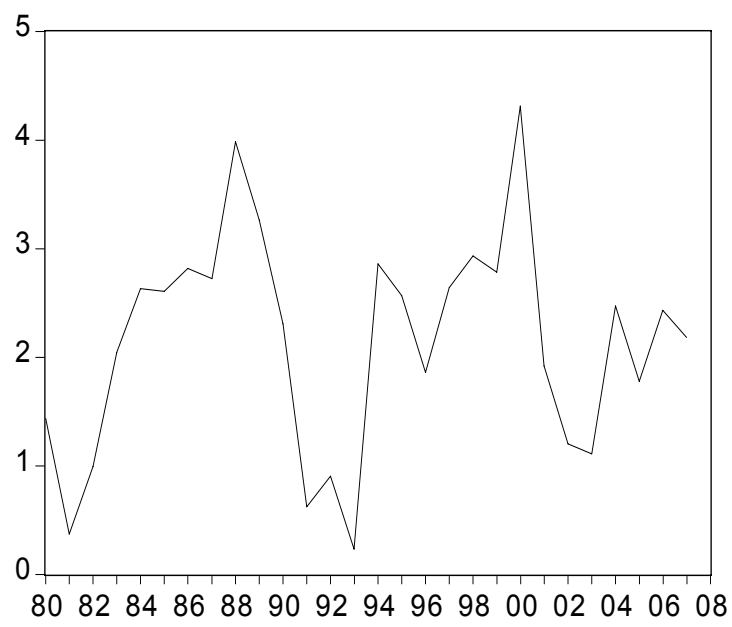

PX

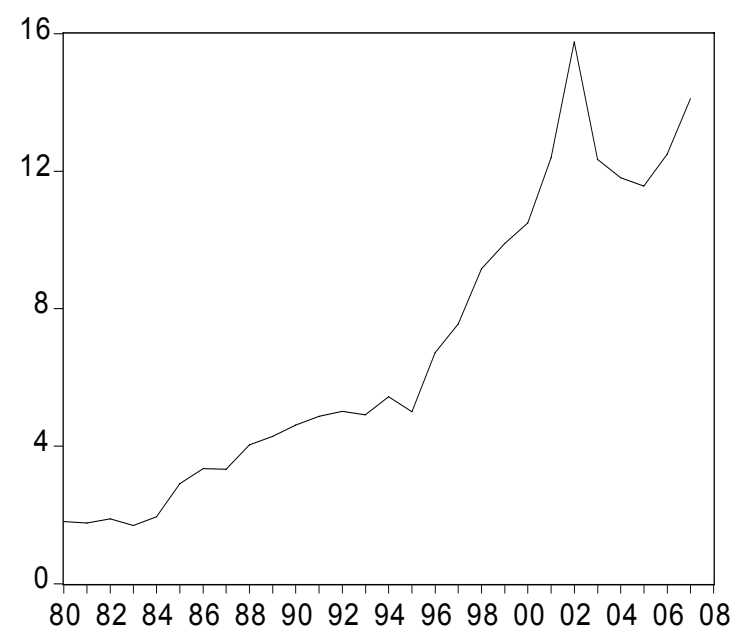

$-\mathrm{V}$

Exchange Rate: 1980-2008

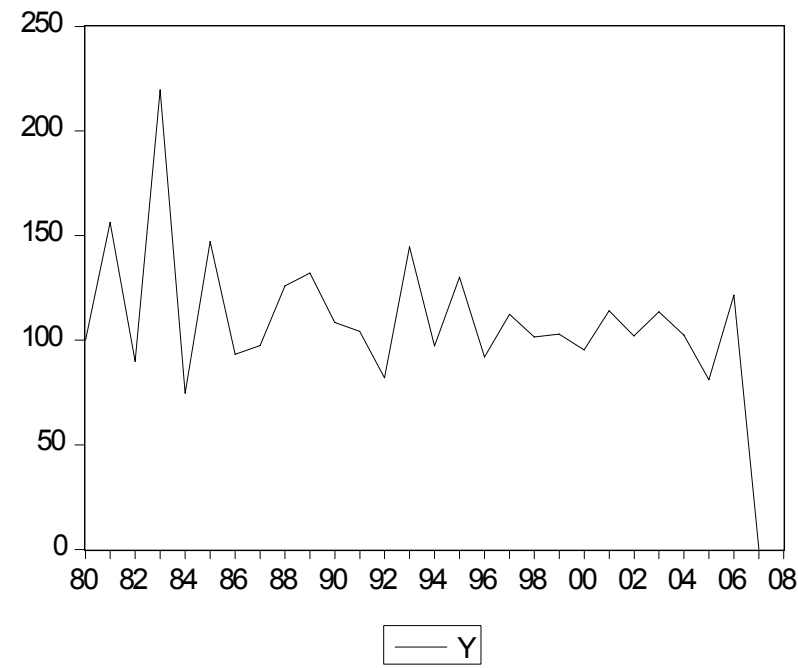

Foreign Income: 1980-2008
Exports: 1980-2008

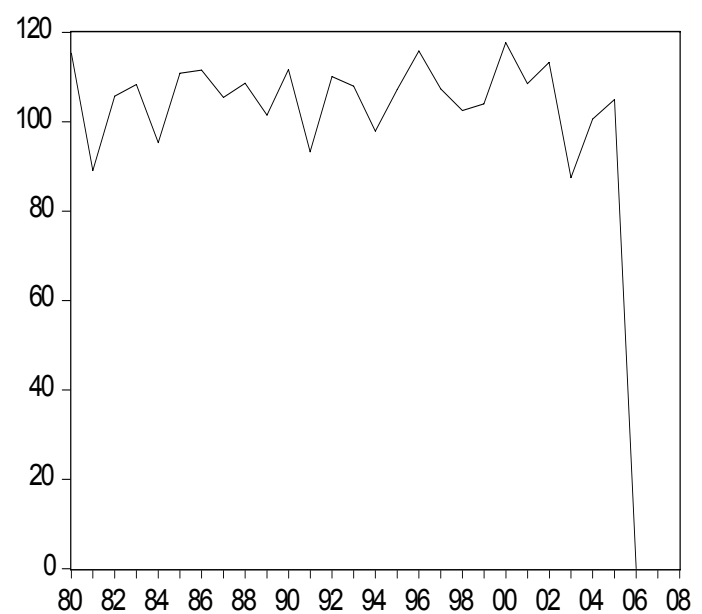

$-\mathrm{X}$

Figure 5. Results for preliminary data examination 


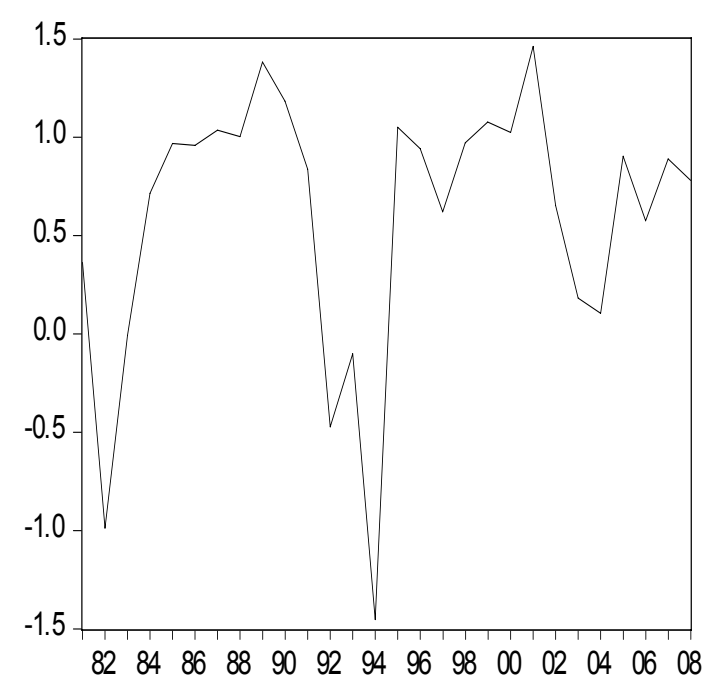

$-\mathrm{LNPX}$

Price of Exports: 1982-2008

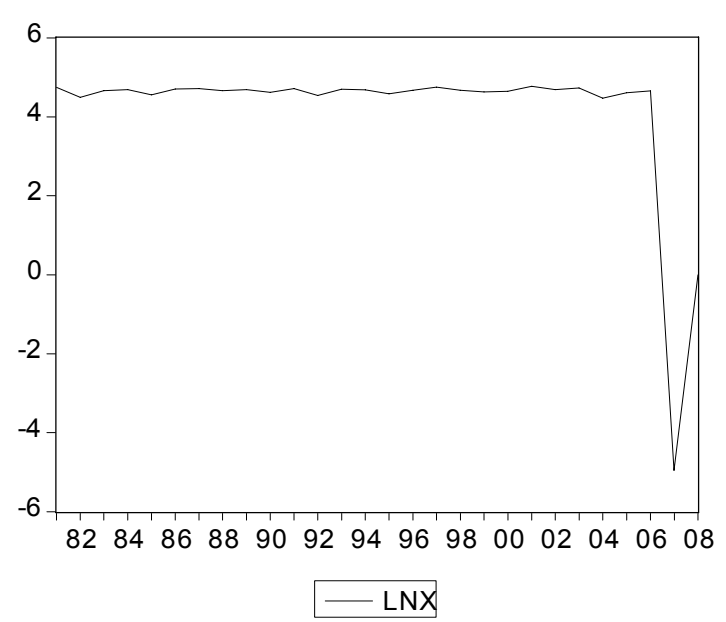

Exports: 1982-2008

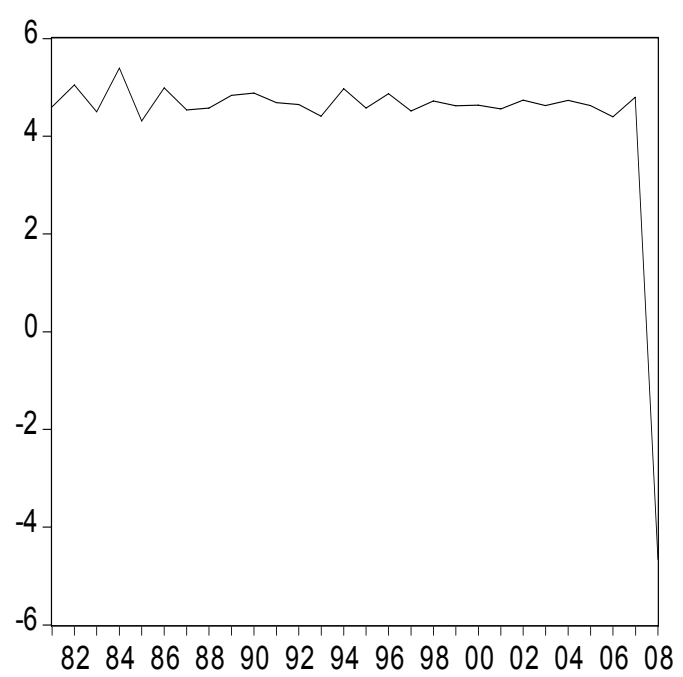

- LNY

Foreign Income: 1982-2008

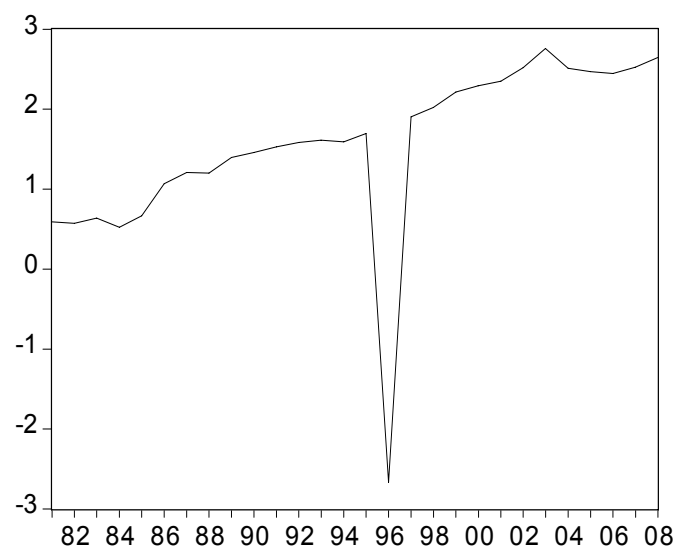

- LNV

Figure 6. Results for preliminary data examination in logarithmic form

All the variables are log-transformed and the residuals of the log-transformed regression are analyzed. In order to be able to check the stationarity of the residuals, the model with logged variables was estimated (for null hypothesis). Table 3 presents the results of the estimated model for residuals with logged variables. Although the estimated model has low R-squared and adjusted R-squared values, the interest here is on the coefficients and a plot for residuals (Brooks, 2006). 
Table 3. Regression results on logged variables

Dependent Variable: $\ln \mathrm{X}$

Method: Least Squares

Date: 02/03/11 Time: 10:31

Sample: 19812008

Included observations: 28

White Heteroskedasticity-Consistent Standard Errors \& Covariance

\begin{tabular}{lllll}
\hline Variable & Coefficient & Std. Error & t-Statistic & Prob. \\
$\ln \mathrm{PX}$ & -0.156334 & 0.250911 & -0.623066 & 0.5391 \\
$\ln \mathrm{Y}$ & 0.393402 & 0.107188 & 3.670192 & 0.0012 \\
$\ln \mathrm{V}$ & -0.300642 & 0.359156 & -0.837080 & 0.4108 \\
$\mathrm{C}$ & 2.987956 & 0.806014 & 3.707077 & 0.0011 \\
R-squared & 0.184771 & Mean dependent var & 4.146045 \\
Adjusted R-squared & 0.082867 & S.D. dependent var & 1.989021 \\
S.E. of regression & 1.904826 & Akaike info criterion & 4.258222 \\
Sum squared resid & 87.08073 & Schwarz criterion & 4.448537 \\
Log likelihood & -55.61511 & F-statistic & 1.813191 \\
Durbin-Watson stat & 2.017817 & Prob(F-statistic) & 0.171685 \\
\hline
\end{tabular}

Source: Computed from "E-views".

Figure 7 plots the residuals of the estimated model for the log-transformed variables.

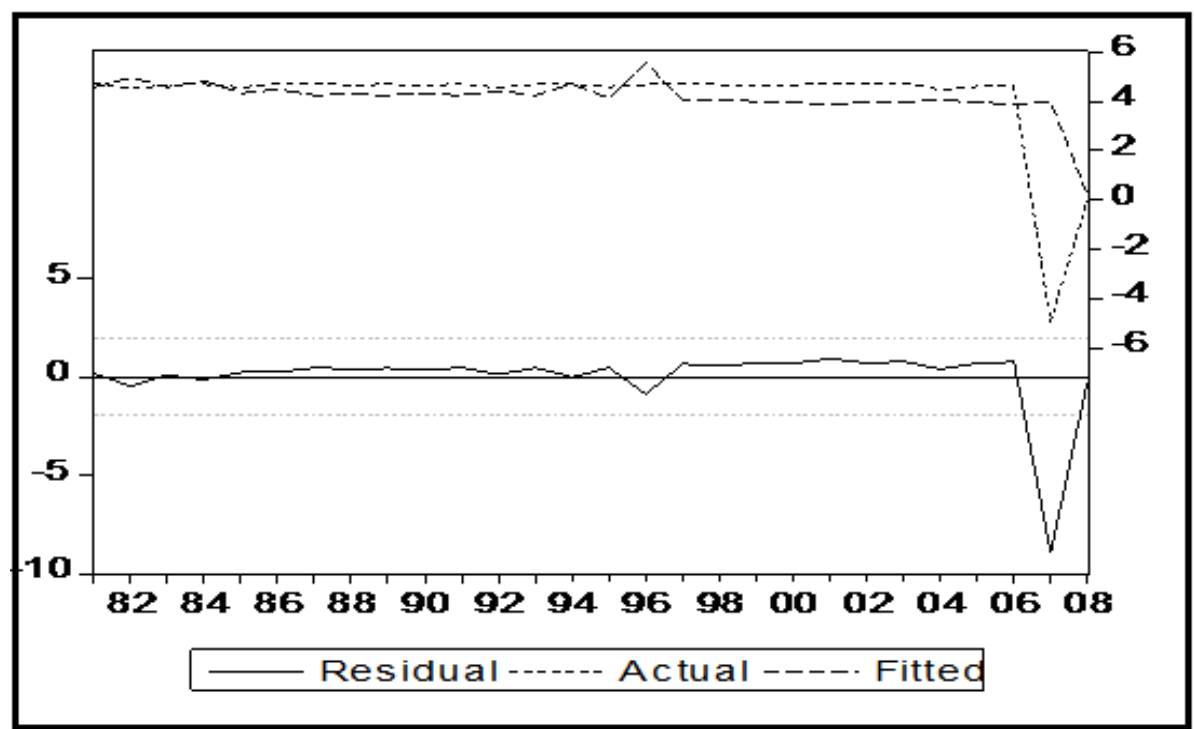

Figure 7. Residual Plot for Stationarity

To ascertain whether or not the residuals are stationary, the ADF test was performed on the residual series although they seem to vary almost evenly around the mean (suggesting that they are stationary). Assuming two lags with no trend, Table 4 presents unit root test results obtained on the residuals. 
Table 4. Unit roots test on residuals

\begin{tabular}{lllc}
\hline & t-Statistic & Percent & Critical value \\
\hline ADF Test Statistic & -5.027451 & $1 \%$ Critical Value* & -3.7497 \\
& & $5 \%$ Critical Value & -2.9969 \\
& & $10 \%$ Critical Value & -2.6381 \\
\hline
\end{tabular}

*MacKinnon critical values for rejection of hypothesis of a unit root.

Source: Computed from ''E-views'.

The results confirm that the residuals of the regression are stationary (since the test statistic is more negative than the critical value) as the residual plot suggested. Therefore, the variables are co-integrated as there seems to be a long-term relationship between the variables. Since there is linear combination of logs of variables that confirmed stationarity, the Error Correction Model (ECM) is estimated. Although the Engle-Granger approach test for co-integration and modeling co-integrated systems could have been easily implemented, it has the major drawback that it can estimate only up to one co-integrating relationship between the variables. For this reason, the more appropriate approach of the Johansen VAR framework was employed. The results are presented in Table 5. It is important to note that the Johansen VAR test is with intercept, no trend in CE as presented below.

Table 5. Johansen co-integration tests results

Date: 02/03/11 Time: 11:45

Sample: 19812008

Included observations: 26

Test assumption: Linear deterministic trend in the data

Series: LNX LNPX LNY LNV

Lags interval: 1 to 1

\begin{tabular}{ccccc} 
& Likelihood & 5 Percent & 1 Percent & Hypothesized \\
Eigenvalue & Ratio & Critical Value & Critical Value & No. of CE(s) \\
0.709604 & 56.65227 & 47.21 & 54.46 & None ** \\
0.434283 & 24.50302 & 29.68 & 35.65 & At most 1 \\
0.285809 & 9.691833 & 15.41 & 20.04 & At most 2 \\
0.035513 & 0.940120 & 3.76 & 6.65 & At most 3 \\
\hline
\end{tabular}

$*(* *)$ denotes rejection of the hypothesis at 5\%(1\%) significance level.

L.R. test indicates 1 cointegrating equation(s) at 5\% significance level.

The Johansen tests statistic in Table 5 above does not indicate any rejection of a null hypothesis of no co-integrating vectors and no co-integrating equation at 5\% significance level. In the case of the likelihood ratio test, the null hypothesis of no co-integration vectors is rejected since the test statistics of 56.65 is greater than the $1 \%$ critical value of 54.46. By looking at the test of null hypothesis of "at most 1 co-integration vector", the likelihood statistic is now 24.50 , whereas the $5 \%$ critical value is 29.68 . Therefore, the null hypothesis is not rejected at $5 \%$ but rejected at $1 \%$ (critical value at $1 \%$ is 35.65 ) because the Likelihood statistics is less than the critical value at $5 \%$ and also less than the critical value even at $1 \%$.

For the null hypothesis of "at most 2", there are 2 co-integrating vectors, the likelihood statistics of 9.69 is far below the $5 \%$ critical value of 15.41 . This strongly suggests that the null hypothesis should not be rejected and there are two co-integrating vectors. Finally, in the case of the null hypothesis of "at most 3" co-integrating vectors, the likelihood statistics of 0,94 is also less than the critical value at $5 \%$ of 3,76 and is even less than the critical value at $1 \%$ of 6.65 which suggests that the null hypothesis shall not be rejected at $5 \%$ (but rejected at $1 \%$ ) critical value. 


\subsection{Vector Error Correction Model (VECM) and Short-Run Relationships}

The Vector Error Correction Model was fitted to allow for clear distinction between long-run and short run impacts of the exchange rate volatility. It is desirable to identify the two co-integrating equations before interpreting the results of the VECM. Table 6 below presents the estimated results for VECM.

Table 6. Vector error correction estimates

\begin{tabular}{lccc}
\hline ERROR CORRECTION: & $\mathrm{D}(\ln \mathrm{PX})$ & $\mathrm{D}(\ln \mathrm{Inc})$ & $\mathrm{D}(\ln \mathrm{V})$ \\
\hline CointEq1 & -1.655462 & -0.078072 & 0.670396 \\
& $(0.54103)$ & $(1.80706)$ & $(0.71895)$ \\
CointEq2 & $(-3.05983)$ & $(-0.04320)$ & $(0.93246)$ \\
& 0.930570 & -3.150307 & -5.478855 \\
& $(3.93349)$ & $(13.1380)$ & $(5.22706)$ \\
& $(0.23658)$ & $(-0.23979)$ & $(-1.04817)$ \\
\hline
\end{tabular}

Source: Computed from "E-views".

In the co-integrating equations presented in Table 6, cointEq2 which is the co-integration of the error correction term $\mathrm{D}(\ln \mathrm{V})$ carries the correct negative sign with the $\mathrm{t}$-value of -5.478855 . The indicator of competitiveness $\mathrm{D}(\ln \mathrm{Px})$ error correction term also carries a correct negative sign with the $\mathrm{t}$-value of -1.655462 . This confirms that the export demand equation constitutes the co-integrating relationship in the first and second co-integrating vectors.

As will be recalled, Equation (1) above was estimated for the top ten agricultural export products to Europe, namely, Apple, Grape, Avocado, Oranges, maize, sugar, pears, apricots, peaches and pineapples. Wine is an important export but is classified differently from the more basic agricultural commodities. The primary export products are identified as apples, grapes, avocados and oranges. The estimates were also done using the computed laspeyres indices for all top ten agricultural exports to the European Union. The actual results obtained from the export demand equation (Equation 1) are presented, with the model performance being augmented by differencing and inclusion of lags. This section attempts to wrap up and gives the practical evidence to the econometric results presented in the foregoing.

\subsection{Ascertaining the Extent of Volatility}

The main interest in this paper is to assess the degree of volatility and how it impacts on export volumes. Hence, the ARCH/GARCH models were employed. By this means, it was possible to obtain some prediction of the extent of volatility or variance of the dependent variable is real exports (denoted by $X$ ) given changes in export pricing in response to exchange rate changes. An ARCH (Autoregressive Conditional Heteroscedasticity) test is obtained by regressing the squared residuals from the model on their first lag and a constant.

Purchasing Power Parity theory suggest that when price of exports increases relative to domestically produced products, it is cheaper to buy the domestically produced products than the imported products (Hoontrakul, 1999; James, 1972; Edwards \& Willcox, 2002; Salvatore, 2004). By looking at the Current Account (CA), Pugel \& Lindert (1996) similarly observe that changes in nominal exchange rate cause changes in the price competitiveness for the country consequently to the net exports. They confirm that changes in exchange rate for a country affect its export and import volumes due to the effect on the competitiveness in the international markets. The expectation is that the higher the price of South African exports to Europe the lower the demand for South African exports in European markets and European consumers (European imports from South Africa).

Against the foregoing theoretical framework, in fitting the model, the order of ARCH (1) and GARCH (1) with GARCH (symmetric) were selected. Durbin Watson of 1.97 (being almost at the optimal value of 2) and the R-squared (0.88) and the adjusted R-squared (0.85) confirm the Goodness-of-fit of the estimated equation. The model with the lowest Akaike Info Criterion (9.050087) and Schwarz criterion (9.386044) is selected. The results are presented in Table 7. The behavior of the individual variables is then examined. Turning to the variables of interest, namely exports, price of exports, foreign income and exchange rate volatility, the results in Table 7 show a positive relationship between real exports as the dependent variable and the price of exports $(\ln \mathrm{Px}=7.68)$. The 
indication is that a $1 \%$ increase in export price for South African leads to a $7.68 \%$ increase in real exports when all other variables are held constant.

Table 7. Results of the ARCH regression procedure

Dependent Variable: $\ln \mathrm{X}$

Method: ML - ARCH

Date: 02/01/11 Time: 16:59

Sample(adjusted): 19802006

Included observations: 27 after adjusting endpoints

Convergence achieved after 377 iterations

\begin{tabular}{lllll}
\hline & Coefficient & Std. Error & z-Statistic & Prob. \\
$\ln \mathrm{PX}$ & 7.680691 & 1.137284 & 6.753538 & 0.0000 \\
$\ln \mathrm{Inc}$ & 0.677922 & 0.030983 & 21.88026 & 0.0000 \\
$\ln \mathrm{V}$ & 1.561100 & 0.151613 & 10.29658 & 0.0000 \\
\multicolumn{2}{c}{ Variance Equation } \\
$\mathrm{C}$ & 4.126542 & 3.069696 & 1.344284 & 0.1789 \\
$\mid \mathrm{RES} /$ /SQR[GARCH](1) & 4.309454 & 1.338082 & 3.220620 & 0.0013 \\
$\mathrm{RES} / \mathrm{SQR}[G A R C H](1)$ & -1.076657 & 0.495768 & -2.171694 & 0.0299 \\
EGARCH(1) & -0.160482 & 0.455188 & -0.352563 & 0.0004 \\
R-squared & 0.884806 & Mean dependent var & 101.5333 \\
Adjusted R-squared & 0.848248 & S.D. dependent var & 21.69443 \\
S.E. of regression & 36.22547 & Akaike info criterion & 9.050087 \\
Sum squared resid & 26245.69 & Schwarz criterion & 9.386044 \\
Log likelihood & -115.1762 & \multicolumn{2}{c}{ Durbin-Watson stat } \\
\hline
\end{tabular}

Source: Computed from eviews.

The exchange rate volatility in the data (shown as $\ln \mathrm{V}$ ) is thus confirmed. But again, a surprising positive sign is observed, confirming the positive relationship between exports and exchange rate volatility of the South African Rand per Euro (ZAR/E). The variable depicts the fact that, when all other variables (namely, foreign income and export price) are held constant, a $1 \%$ increase in exchange rate bring about $1.56 \%$ increase in real exports. The positive relationship supports the view that some form of the depreciation of the rand stimulates exports as well as the economic growth of the country. Foreign income $(\ln I n c)$ carries a positive sign. This is not surprising because according to the theorists, an increased foreign income means an increased foreign demand resulting to an increase in real exports. The variable portrays that a $1 \%$ increase in foreign income brings about $0.68 \%$ increase in exports. 


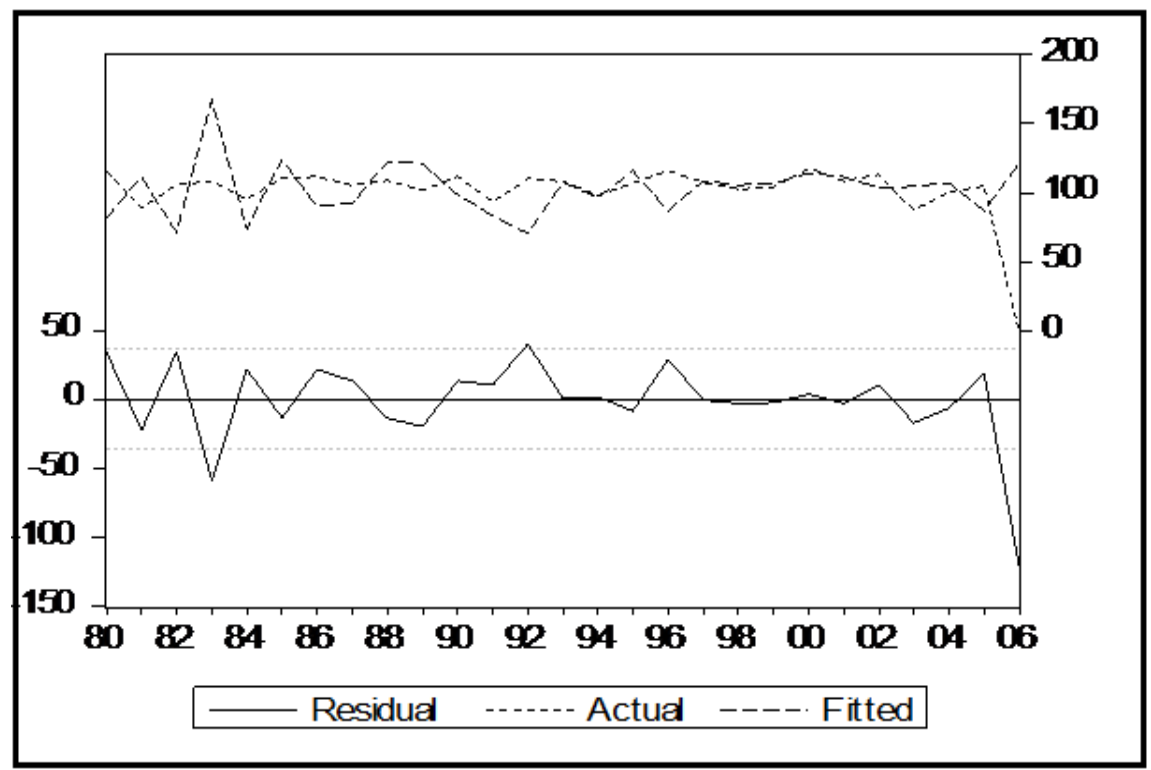

Figure 8. Comparison of actual versus fitted values

In Figure 8, where the actual versus fitted results are compared, the robustness of the model is confirmed. The stationarity of the variables in the estimated equation and the significance of the EGARCH also confirm the robustness of the model. Figure 9 presents the normality test of the estimated results, both Figure 8 and 9 emphasizes a reasonable good fit of the estimated model.

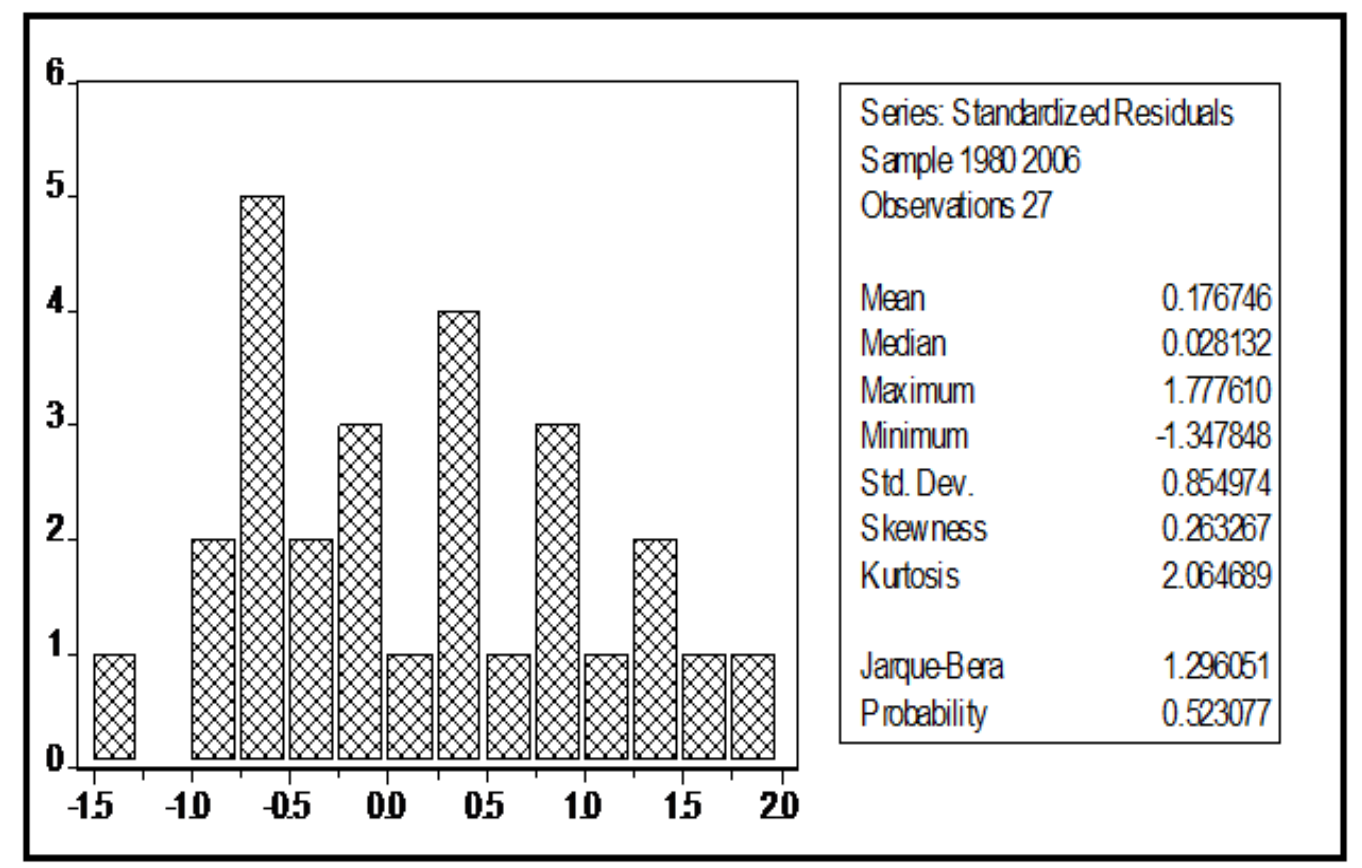

Figure 9. Normality test

\subsection{Results for Primary Agricultural Exports}

The regression results were enhanced by $\log$ transmission of all variable in the data. Although the results were not that robust to some of them as shown by annexures A to D, although they were statistically significant (except for income on apples), the diagnostic checks shows that not all of the tests perfectly fit the model. The tests were also 
done for residual, actual versus fitted as well as the normality tests attached in the annexure also proves that the tests were not perfect. It should be noted that at this particular point in time the interest is on the relationship between the variables of interest when the tests are done specifically for each product.

In Table 8 below, a unit change in exports $(\ln \mathrm{X})$ (dependent variable) will cause the coefficients to change by the value indicated. The results are amazing because that foreign income $(\ln \mathrm{Y})$ on apples and on orange shows the negative relationship with exports $(\ln \mathrm{X})$. This contradicts the theory as Appleyard, Field and Cobb (2006) suggest that an increased foreign income means high external demand for domestically produced good. The positive relationship between export price $(\ln \mathrm{Px})$ and exports $(\ln \mathrm{X})$ was anticipated because the profit maximizing firm sells the products where the price is said to be high. Therefore, the higher the price of exports (X) the higher the exports (x). Because export price is the indicator of competitiveness, the higher the price of exported products by South Africa relative to other countries of the world the less competitive are its exports.

Table 8. Regression results for primary agricultural exports

\begin{tabular}{lllll}
\hline APPLES & Coefficient & Std. Error & z-Statistic & Prob. \\
\hline $\ln \mathrm{PX}$ & 0.147793 & 0.000326 & 453.9574 & 0.0000 \\
$\ln \mathrm{Y}$ & -0.030671 & 0.024577 & -1.247961 & 0.2120 \\
$\ln \mathrm{V}$ & 0.028587 & 0.001661 & 17.21174 & 0.0000 \\
$\mathrm{C}$ & 11.19394 & 0.023710 & 472.1148 & 0.0000 \\
AVOCADOS & & & & \\
$\ln \mathrm{PX}$ & 0.577317 & 0.128065 & 4.507999 & 0.0000 \\
$\ln \mathrm{Y}$ & 0.180330 & 0.049926 & 3.611981 & 0.0003 \\
$\ln \mathrm{V}$ & 0.180788 & 0.069860 & 2.587861 & 0.0097 \\
$\mathrm{C}$ & 5.366807 & 0.923134 & 5.813680 & 0.0000 \\
ORANGES & & & & \\
$\ln \mathrm{Y}$ & -0.110744 & 0.017149 & -6.457621 & 0.0000 \\
$\ln \mathrm{PX}$ & 0.338382 & 0.017327 & 19.52871 & 0.0000 \\
$\ln \mathrm{V}$ & 0.116656 & 0.011017 & 10.58847 & 0.0000 \\
$\mathrm{C}$ & 10.53755 & 0.116657 & 90.32970 & 0.0000 \\
GRAPES & & & & \\
$\ln \mathrm{PX}$ & 0.495712 & $1.28 \mathrm{E}-06$ & 388503.8 & 0.0000 \\
$\ln \mathrm{Y}$ & 0.438143 & 0.007149 & 61.29157 & 0.0000 \\
$\ln \mathrm{V}$ & 0.417464 & 0.004677 & 89.24991 & 0.0000 \\
$\mathrm{C}$ & 6.243593 & 0.005217 & 1196.685 & 0.0000 \\
\hline $\mathrm{S}$ & & &
\end{tabular}

Source: Computed from "E-views".

The relationship between the exchange rate volatility $(\ln \mathrm{V})$ and exports $(\mathrm{X})$ is positive for all the products (Table 8 above). The relationship is also unexpected because volatile exchange rate means risk for speculators and they are risk averse as they seek to maximize profits. The positive results could mean that because South Africa Rand loses its value then South Africa exports become cheaper abroad as they enter the international market at lower prices (thus becoming more competitive) relative to other countries exports. Therefore, the positive relationship means benefit to South African economy because increased exports come as a result of increased Euros that South Africa earn.

\subsection{Results of the Constant Market Share Analysis}

The results of the Constant Market Share Analysis are presented in this sub-section. Three factors used to explain the reasons for the growth of a country's exports were analysed. These are the factors relating to the growth of the export market relative to the world export growth (structural effect), improvements in competitiveness of the 
exporting country (competitive effect) and the combined effect of competitiveness and structure (second order effect) (Barbaros, Akgungor, \& Aydogus, 2007). A positive index denotes a competitive scenario.

The competitive effect contributed positively to the increase of orange exports in Greece, Italy, Portugal, United Kingdom, Asian and Northern Europe markets (Table 9). However, South African oranges were not competitive in France, Spain and Eastern Europe markets.

While there is a positive general competitiveness of the South African lemons and limes in the Americas, the changes in the import quantities had a greater influence compared to the general improvement on competitiveness (competitive effect) of the industry (Table 10). The lemons also performed positively in Oman and Africa for the period 2000 to 2004. However, the performance declined for the period 2005-2008. The competitiveness of the South African lemons and limes deteriorated in the European, South Eastern Asia and Oceania despite the positive Constant Market Share indices.

Table 9. The CMSanalysis of the south african oranges (2000-2008)

\begin{tabular}{|c|c|c|c|c|c|c|}
\hline & \multicolumn{3}{|c|}{ 2000- 2004} & \multicolumn{3}{|c|}{ 2005-2008 } \\
\hline & $\begin{array}{l}\text { Structural } \\
\text { Effect }\end{array}$ & $\begin{array}{l}\text { Competitive } \\
\text { effect }\end{array}$ & $\begin{array}{l}\text { Second } \\
\text { order effect }\end{array}$ & $\begin{array}{l}\text { Structural } \\
\text { Effect }\end{array}$ & $\begin{array}{l}\text { Competitive } \\
\text { effect }\end{array}$ & $\begin{array}{l}\text { Second } \\
\text { order effect }\end{array}$ \\
\hline Belgium & -0.05 & -0.18 & 0.01 & -0.07 & 0.02 & -0.01 \\
\hline France & 1.43 & -0.03 & -0.61 & -1.64 & -0.05 & -1.59 \\
\hline Greece & 0.08 & -0.85 & -0.18 & -0.06 & 0.19 & 0.00 \\
\hline Italy & 1.18 & 0.14 & -0.33 & -0.72 & 0.22 & -4.00 \\
\hline Netherlands & -0.02 & 0.05 & -0.02 & 0.40 & 0.01 & -0.14 \\
\hline Portugal & -0.81 & -0.11 & -0.69 & 3.60 & 0.63 & 0.62 \\
\hline Spain & 0.51 & -0.10 & -0.42 & 0.03 & -0.01 & 0.02 \\
\hline $\begin{array}{l}\text { United } \\
\text { Kingdom }\end{array}$ & 0.10 & -0.12 & -0.01 & -0.14 & 0.08 & -0.03 \\
\hline Africa & 1.00 & 0.12 & 0.11 & 0.25 & -0.04 & 0.08 \\
\hline Americas & 0.19 & 0.09 & 0.03 & 0.50 & 0.02 & 0.96 \\
\hline Asia & 0.17 & -0.04 & -0.03 & -0.02 & 0.26 & -0.08 \\
\hline $\begin{array}{l}\text { Eastern } \\
\text { Europe }\end{array}$ & 1.58 & 0.42 & 1.22 & 1.78 & 0.04 & -0.50 \\
\hline $\begin{array}{l}\text { Northern } \\
\text { Europe }\end{array}$ & 39.05 & 0.10 & 10.61 & -24.09 & 0.18 & -204.09 \\
\hline $\begin{array}{l}\text { Southern } \\
\text { Europe }\end{array}$ & 13.69 & -0.21 & -9.02 & 0.36 & -0.01 & -0.96 \\
\hline
\end{tabular}

Source: Own calculations based on data from FAOSTAT, 2010 and DAFF, 2010b. 
Table 10. The CMS Analysis of the South African Lemons and Limes (2000-2008)

\begin{tabular}{|c|c|c|c|c|c|c|}
\hline & \multicolumn{3}{|c|}{ 2000- 2004} & \multicolumn{3}{|c|}{ 2005-2008 } \\
\hline & $\begin{array}{l}\text { Structural } \\
\text { Effect }\end{array}$ & $\begin{array}{l}\text { Competitive } \\
\text { effect }\end{array}$ & $\begin{array}{l}\text { Second } \\
\text { Order effect }\end{array}$ & $\begin{array}{l}\text { Structural } \\
\text { Effect }\end{array}$ & $\begin{array}{l}\text { Competitive } \\
\text { effect }\end{array}$ & $\begin{array}{l}\text { Second } \\
\text { Order effect }\end{array}$ \\
\hline Bahrain & 0.91 & 0.42 & 0.22 & -0.64 & 0.01 & 0.10 \\
\hline Kuwait & -6.59 & 0.79 & -6.40 & 6.00 & 0.45 & 573.67 \\
\hline Oman & 5.03 & 1.74 & 63.48 & -7.31 & 5.77 & -255.46 \\
\hline Qatar & -3.18 & 0.46 & -1.57 & 3.56 & -0.10 & -0.49 \\
\hline Saudi Arabia & -0.25 & 0.62 & -0.17 & 0.53 & -0.37 & -0.82 \\
\hline $\begin{array}{l}\text { United Arab } \\
\text { Emirates }\end{array}$ & 0.20 & 0.28 & -0.01 & 0.53 & 0.00 & -16.82 \\
\hline Africa & 0.01 & 0.42 & 0.04 & 0.25 & -0.24 & -0.87 \\
\hline Americas & 82.65 & 0.30 & 9.72 & 51.56 & 0.78 & 129.05 \\
\hline Europe & 1.23 & 0.38 & 0.69 & 1.19 & 0.16 & 0.49 \\
\hline Oceania & 0.64 & 0.25 & 0.64 & 0.61 & -0.25 & 0.43 \\
\hline $\begin{array}{l}\text { South Eastern } \\
\text { Asia }\end{array}$ & 0.18 & 0.22 & 0.28 & 0.18 & 0.15 & 0.03 \\
\hline
\end{tabular}

Source: Own calculations based on data from FAOSTAT, 2010 and DAFF, $2010 \mathrm{~b}$.

South Africa was able to increase its grapefruit exports to Eastern Europe, Germany, Denmark and South Eastern Asia (Table 11). South African grapefruits have shown an upward trend of competitiveness in China, Hong Kong and Denmark between 2000 and 2008. The growth was mainly attributed to the growth of the imports in these markets as reflected by the rise in structural effect. However, the competitive effect in markets such as France, Greece, Italy, Netherlands and Spain show a downward trend.

Table 11. The CMS analysis of the south african grapefruits (including pomelos) (2000-2008)

\begin{tabular}{|c|c|c|c|c|c|c|}
\hline & \multicolumn{3}{|c|}{$2000-2004$} & \multicolumn{3}{|c|}{ 2005-2008 } \\
\hline & $\begin{array}{l}\text { Structural } \\
\text { Effect }\end{array}$ & $\begin{array}{l}\text { Competitive } \\
\text { effect }\end{array}$ & $\begin{array}{l}\text { Second } \\
\text { Order effect }\end{array}$ & $\begin{array}{l}\text { Structural } \\
\text { Effect }\end{array}$ & $\begin{array}{l}\text { Competitive } \\
\text { effect }\end{array}$ & $\begin{array}{l}\text { Second order } \\
\text { effect }\end{array}$ \\
\hline Belgium & -0.29 & -0.08 & 0.05 & 0.21 & -0.08 & 0.00 \\
\hline China & -9.43 & 0.06 & 1.29 & -6.62 & 0.39 & 0.25 \\
\hline Hong Kong & -0.57 & -0.13 & 0.36 & 0.00 & 0.24 & -1.64 \\
\hline Denmark & -0.61 & 0.00 & -6.29 & 1.71 & 5.91 & 44.86 \\
\hline France & -0.57 & 0.10 & 0.37 & -0.82 & -0.10 & -0.32 \\
\hline Germany & -5.25 & 2.03 & -19.50 & 9.17 & -0.99 & -26.41 \\
\hline Greece & 0.51 & 0.00 & 0.24 & -0.04 & -0.23 & 0.62 \\
\hline Italy & 0.13 & 0.44 & 0.45 & -0.39 & -0.31 & -0.11 \\
\hline Japan & 0.14 & 0.35 & -0.12 & -0.90 & 0.16 & -8.81 \\
\hline Netherlands & -0.34 & 0.26 & -0.09 & 0.47 & -0.24 & -0.21 \\
\hline $\begin{array}{l}\text { Republic of } \\
\text { Korea }\end{array}$ & -0.34 & -0.25 & -0.01 & 20.06 & 0.00 & -156.56 \\
\hline Spain & 0.84 & 0.35 & -0.20 & 0.82 & -0.30 & 2.27 \\
\hline Sweden & 6.99 & 0.35 & 3.82 & 3.36 & 1.12 & -49.78 \\
\hline $\begin{array}{l}\text { United } \\
\text { Kingdom }\end{array}$ & -0.14 & 0.02 & 0.05 & -0.23 & 0.10 & -0.02 \\
\hline Africa & 0.13 & 0.23 & -0.17 & -0.05 & -0.25 & -0.22 \\
\hline Americas & -0.47 & -0.08 & -0.21 & 0.11 & 0.02 & -2.13 \\
\hline Asia & 0.26 & 0.25 & -0.11 & -0.78 & 0.13 & -4.66 \\
\hline S.Eastern Asia & 0.49 & 0.24 & -1.16 & 2.16 & -0.07 & -1.75 \\
\hline Eastern Europe & 61.60 & 4.53 & 135.65 & 100.97 & 2.35 & 452.70 \\
\hline Northern & & & & & & \\
\hline Europe & 0.00 & 0.00 & 0.00 & -365.25 & 3.53 & -3366.58 \\
\hline
\end{tabular}

Source: Own calculations based on data from FAOSTAT, 2010 and DAFF, $2010 \mathrm{~b}$.

No fruit was exported to Czech Republic between 2000 and 2004 (Table 12). The change in exports to the United Kingdom market declined between the periods 2000-2004 and 2005-2008 as manifested by the structural effect. 
While the South African soft citrus fruit showed some significant competitiveness, the amounts exported to the UK market did not increase in proportion to the general increase in the quantity of the soft citrus imported in the same period. Increase in the import volumes in Eastern Europe impacted positively on the South African soft citrus exports as indicated by the rise in the structural effect from 80.53 to 269.46 between the periods $2000-2004$ and 2005-2008. Increases in Asian soft citrus imports contributed to the positive export performance of the South African soft citrus as marked by the structural effect index rising from -0.19 to 8.39 .

Table 12. The CMS analysis of the south african soft citrus (2000-2008)

\begin{tabular}{|c|c|c|c|c|c|c|}
\hline & \multicolumn{3}{|c|}{ 2000- 2004} & \multicolumn{3}{|c|}{ 2005- 2008} \\
\hline & $\begin{array}{l}\text { Structural } \\
\text { Effect }\end{array}$ & $\begin{array}{l}\text { Competitive } \\
\text { effect }\end{array}$ & $\begin{array}{l}\text { Second order } \\
\text { effect }\end{array}$ & $\begin{array}{l}\text { Structural } \\
\text { Effect }\end{array}$ & $\begin{array}{l}\text { Competitive } \\
\text { effect }\end{array}$ & $\begin{array}{l}\text { Second order } \\
\text { effect }\end{array}$ \\
\hline Czech & & & & & & \\
\hline Republic & 0 & 0 & 0 & -57.03 & 0.07 & 69.08 \\
\hline Ireland & 1.67 & -0.23 & -3.24 & 8.41 & 1.75 & 13.78 \\
\hline Netherlands & 1.95 & 0.03 & 1.10 & 1.22 & 0.04 & -0.76 \\
\hline Slovenia & -1.70 & -0.02 & 0.17 & 1.56 & 0.00 & 0.00 \\
\hline United & & & & & & \\
\hline Kingdom & 0.82 & -0.06 & -0.03 & -0.32 & 0.11 & -0.05 \\
\hline Africa & 0.11 & -0.16 & -0.01 & 0.49 & -0.03 & -0.02 \\
\hline Americas & -0.26 & 0.01 & 0.25 & 0.87 & -0.17 & 0.06 \\
\hline Asia & -0.19 & -0.10 & -0.09 & 8.39 & 0.01 & -0.28 \\
\hline Eastern & & & & & & \\
\hline Europe & 80.53 & 3.18 & 361.20 & 269.46 & 0.41 & -944.71 \\
\hline Northern & & & & & & \\
\hline Europe & 344.47 & 0.00 & -31.72 & -3.35 & 0.30 & 24.55 \\
\hline
\end{tabular}

Source: Own calculations based on data from FAOSTAT and DAFF, 2010b.

South African trade data to the newly emerging markets (Middle East, Russia, Japan) was not available for the period ranging 2000 to 2008. However, Figure 10 shows the current share of volumes exported to these markets in relation to the other markets during 2008 and 2010. The percentage of oranges exported to the Russian market rose from $11 \%$ in the 2008 to $14 \%$ in the 2010 seasons (CGA, 2010b; 2009a). For the Middle East market the percentage of oranges rose from $18 \%$ to $23 \%$ for the two seasons.
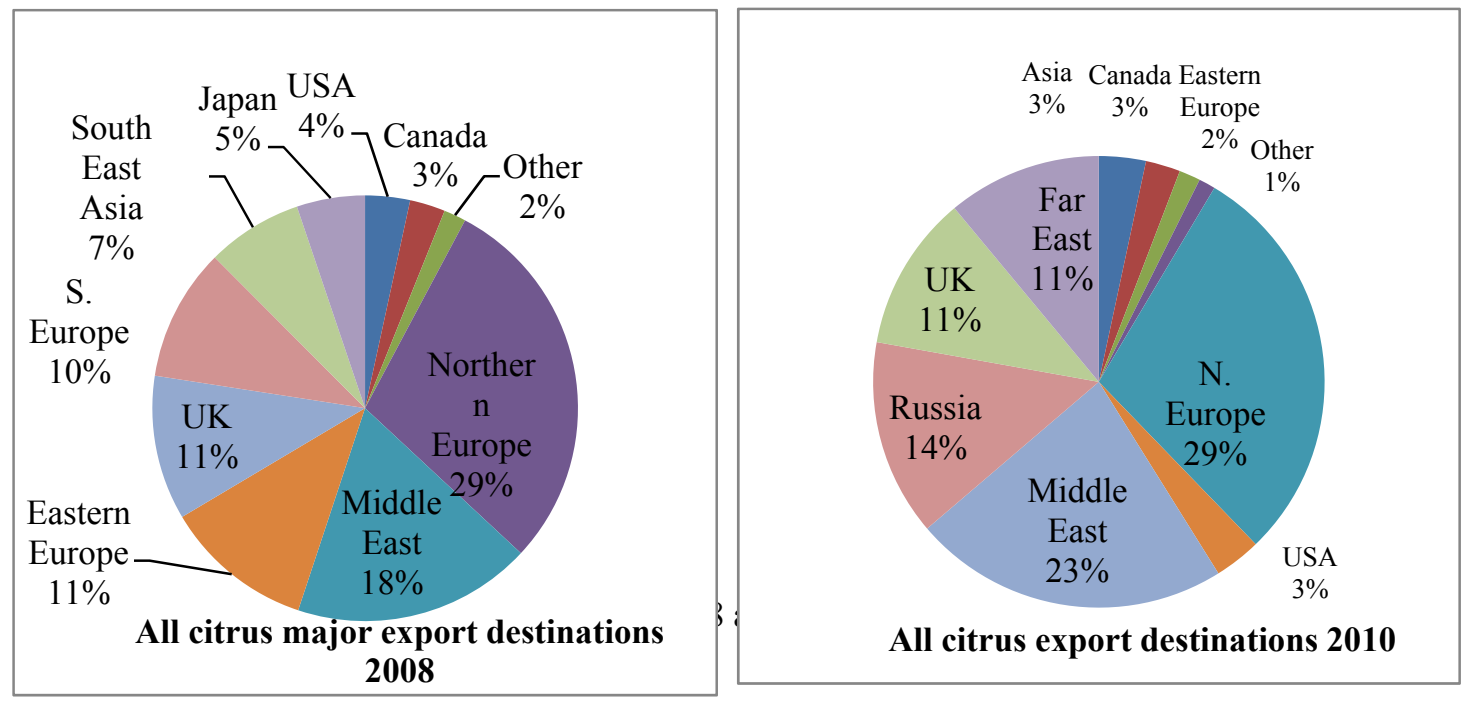

\section{Conclusion}

On the basis of the regression results and the constant market share analysis, it can be concluded that South Africa's agricultural exports are becoming more competitive in the European and other markets in recent years and despite the global financial crisis. While the Rand has lost value over the past few years covered by this study, which would theoretically have been consistent with declining export prices and improved competitiveness, there 
was clear evidence of high volatility which in and of itself is expected to have led to considerable instability in the market and a possible loss of competitiveness. Thus, the sector has been subject to quite contradictory conditions that have been pulling it in both directions. To this extent, the positive relationship between exports and the exchange rate is surprising. Similarly, the evidence that the market share of the product has generally been on the increase in most of the important export destinations in Europe, Middle East and elsewhere come against the backdrop of the unfavourable global financial developments. These situations call for some explanation. In the first place, the importing countries have limited choices in terms of alternative sources of the product which means that the price elasticity of demand for the imported citrus will be quite low. South Africa remains a dominant citrus producing country and South Africa's agricultural exports for the top ten commodities are ranked among the first five in the European markets and the first ten for the world. Thus, even if the exchange rate developments lead to rising export prices, consumers in the importing countries will not have the flexibility to move to other sources of the products or even to move away from citrus given, again, that it has no close substitutes.

But it is possible that much of the improvement in market share and export competitiveness came as a result of price effects. Despite the volatility in the exchange rates, export prices are still worked out at a given point in time on the basis of contracts. Thus, even if those prices are subject to swings while remaining below some reference international price, the product would still be competitive. Exchange rate volatility would normally have a deleterious effect on export volumes if it results on episodes of higher than normal prices. This was obviously not the case. The results are supported by previous documented research, which emphasized that the weaker rand leads to more South African agricultural produce being absorbed by the international markets (European Union in this case). This is because, the weaker rand means that South African products enter the international market at the lower prices compared to other countries. This stimulates the competitiveness of South African agricultural exports. Thus, the results reject the null hypothesis that exchange rate volatility depresses competitiveness of South Africa's agricultural exports. The evidence from the study is that exchange rate volatility may actually be irrelevant in determining the degree of export competitiveness as long as it does not push prices above international prices. When the CMS results were examined separately, it was clear that the industry has maintained its competitive advantage in several markets. For instance, the results showed that South Africa's lemons are competitive in America. Despite a negative trend, the South African grapefruit has been competitive in France, Greece, Italy, the Netherlands and Spain. Oranges have been competitive in the Greece, Italy, Portugal, UK, Asian and Northern Europe markets. Competitiveness in these markets has been due to the inherent competitiveness of the industry. Competitiveness in such markets as the Middle East has been attributed to the relatively rapid growth of these markets.

\section{Implications for Enterprise Development and Management}

The crucial need in South Africa is for the restructuring of the countries agricultural sector to create more opportunities for the previously disadvantaged black population now entering the agricultural economy in the new era of democratic governance. There is strong interest in commercialization of smallholder farming which means that the mechanisms and macroeconomic aggregates that influence incentives will be interesting subjects for study. How these factors affect new entrants into the farming is an issue that the South African government is managing quite deftly and a number of recent policies are pointing in the right direction. It will be helpful for future and more inclusive policy processes to use systematic analysis of this type to lend strong scientific support to such efforts.

\section{References}

Ahmadi-Esfahani, F. Z. (2006). Constant market shares analysis: uses, limitations and prospects. The Australian Journal of Agricultural and Resource Economics, 50, 510-526. http://dx.doi.org/10.1111/j.1467-8489.2006.00364.x

Akgul, I., \& Sayyen, H. (2008). Modeling and forecasting long Memory in exchange rate volatility vs. stable and integrated GARCH models. Applied Financial Economics, 18, (463-482). http://dx.doi.org/10.1080/09603100600959860

Aljandali, A. K. (2012). Currency volatilities in Africa: the case of Southern African Development Community (SADC). In E. E. Obuah (Ed.), African Business and Development in a Changing Global Political Economy: Issues, Challenges and Opportunities. Peer-Reviewed Proceedings of the $13^{\text {th }}$ Annual International Conference of the International Academy of African Business and Development (IAABD), May 15-19, 2012 Casablanca, Morocco.

Appleyard, D. R., Field, J. A., \& Cobb, S. L. (2006). International Economics (5th ed.). New York: McGraw-Hill Irwin. 
Barbaros, R, F., Akgungor, S., \& Aydogus, O. (2007). Competitiveness of Turkey's Organic Exports in the European Union Market Contributed Paper prepared for presentation at the 105th EAAE Seminar International Marketing and International Trade of Quality Food Products. Bologna, Italy, March 8-10, 2007.

Bhattarai, K. R., \& Armah, M. K. (2005). The Effects of Exchange Rate on the Trade Balance in Ghana: Evidence from Cointegration Analysis. Research Memorandum 52 August 2005, Centre for Economic Policy Business School, University of Hull.

Bollerslev, T. (1986). Generalized Autoregressive Conditional Heteroscedasticity. Journal of Econometrics, 31, 307-327. http://dx.doi.org/10.1016/0304-4076(86)90063-1

Box, G., \& Jenkins, G. (1970). Time series analysis: Forecasting and control, San Francisco: Holden-Day.

Brooks, C. (2006). Introductory Econometrics for Finance (7th ed.). Cambridge: Cambridge University Press.

Cameron, S., Kihangire, D., \& Potts, D. (2001). Has exchange rate volatility reduced Ugandan coffee exports? Bradford Centre for International Development (BCID). United Kingdom.

CGA (Citrus Growers Association). (2010b). Review 2010: Russia. Retrieved March 2011 from www.cga.co.za

CGA. (2009a). CGA Annual Report 2009. Citrus Growers Association of Southern Africa. Retrieved 2 March, 2011, from www.cga.co.za

Chen, K., \& Duan, Y. (2001). Competitiveness of Canadian Agri-food Exports Against Competitors in Asia: 1980-97. Project Report, Edmonton, Department of Rural Economy, University of Alberta, Canada.

Chit, M. M., Rizov, M., \& Willenbockel, D. (2010). Exchange Rate Volatility and Exports: New Empirical Evidence from the Emerging East Asian Economies. The World Economy, Blackwell Publishing Ltd. http://dx.doi.org/10.1111/j.1467-9701.2009.01230.x

Edwards, L., \& Willcox, O. (2002). Exchange rate depreciation and the trade balance in South Africa. Report Prepared for the National Treasury of South Africa. Retrieved from https://www.commerce.uct.ac.za/Economics/.../ledwards/.../BOPreport5.d

Engle, R. F. (1982). Autoregressive Conditional Heterescedasticity with estimates of the Variance of UK inflation. Econometrica, 50(4). http://dx.doi.org/10.2307/1912773

Evans, T., \& McMillan, D. G. (2007). Volatility forecasts: the role of asymmetric and long-memory dynamics and regional evidence. Applied Financial Economics, 17, http://dx.doi.org/10.1080/09603100601007149

Fabiosa J. F. (2002). Assessing the Impact of the Exchange Rate Volatility and Its Impact on Canadian Pork and Live Swine Exports to the United States and Japan. Working Paper, No. 02-WP305, June 2002. Central of Agriculture and Rural Development, Canada.

Fountas, S., \& Aristotelous, K. (1999). The Impact of Exchange Rate Regime on Exports: Evidence from the European Monetary System, Working Papers 38, National University of Ireland Galway, Department of Economics, revisited 1999. Retrieved 24 April, 2011, from http://idease.repec.org/e/pfo35.html

Fountas, S., \& Aristotelous, K. (1999). The Impact of Exchange Rate Regime on Exports: Evidence from Bilateral Exports in the European Monetary System. Working Papers 40, National University of Ireland Galway, Department of Economics, revisited 1999. Retrieved 24 April, 2011, from http://idease.repec.org/e/pfo35.html

Fountas, S., \& Aristotelous, K. (2000). The Impact of Exchange Rate Regime on Export Volumes? Evidence from Bilateral Exports in the US-UK Trade: 1900-1998. Working Papers 43, National University of Ireland Galway, Department of Economics, revisited 1999. Retrieved 24 April, 2011, from www.economics.nuig.ie/resrch/pdf/paper_0043.pdf

Hoontrakul, P. (1999). Exchange Rate Theory: A Review. Discussion Paper, Chulalongkorn University, Thailand. James, C. (1972). Economic Development and Economic growth (5th ed.). New York: Quadrangle Books.

McAfee, R. P. (2006). Introduction to economic analysis. California: California Institute of Technology.

Milana, C. (1988). Constant Market Shares analysis and Index number theory. European Journal of Political Economy, 4(4), 453-478. http://dx.doi.org/10.1016/0176-2680(88)90011-0 
Musila, J., \& Al-Zyoud, H. (2012). Exchange rate volatility and international trade flows in sub-Saharan Africa: empirical evidence. Journal of African Business, 13(2). http://dx.doi.org/10.1080/15228916.2012.693440

Porter, M. (1990). The Competitive advantage of nations (2nd ed.). London: Macmillan.

Porter, M. E. (1998). On competition. USA: Harvard Business Review Book Series.

Pugel, T. A., \& Lindert, P. H. (1996). International Economics (tenth edition). Chocago: Irwin.

Salvatore, D. (2004). International Economics (8th ed.). USA: John Willey and Sons.

Salvatore, D. (2007). International Economics (9th ed.). USA: John Willey and Sons.

Siggel, E. (2006). International competitiveness and comparative advantage: A survey and a proposal for measurement. Springer Science + Business Media, LLC 2006. Journal of Industry, Competition and Trade, 6, 137-159. http://dx.doi.org/10.1007/s10842-006-8430-x

Sun, C., Kim, M., Koo, W., Cho, G., \& Jin, H. (2002). The Effect of Exchange Rate Volatility on Wheat Trade Worldwide. Agribusiness \& Applied Economics Report No. 488, Centre for Agricultural Policy and Trade Studies, North Dakota State University.

Todani. K. R., \& Munyama, T. V. (2005). Exchange Rate Volatility and Exports in South Africa. Development Policy Research Unit, University of Cape Town.

Tyszynski, H. (1951). World trade in manufactured commodities, 1899-1950. The Manchester School of Economic Social Studies, 19, 272-304. http://dx.doi.org/10.1111/j.1467-9957.1951.tb00012.x

Van der Merwe, E. J. (1997). Exchange Rate Management Policies in South Africa: Recent Experience and Prospects. South African Reserve Bank, Unpublished paper. Retrieved 07 April, 2007, from http://www.uneca.org/eca_resources/Major_ECA_Websites/6finmin/experm2.htm

\section{Copyrights}

Copyright for this article is retained by the author(s), with first publication rights granted to the journal.

This is an open-access article distributed under the terms and conditions of the Creative Commons Attribution license (http://creativecommons.org/licenses/by/3.0/). 